\title{
Determinación de cargas dinámicas de camiones pesados que transitan en un puente basado en algoritmos genéticos e instrumentación
}

\section{Genetic algorithms and instrumentation determination of dynamic loads of heavy trucks over a bridge}

\author{
Edgar Muñoz*1, David Gómez*, Federico Núñez** y Carlos Florez* \\ * Pontificia Universidad Javeriana de Colombia. COLOMBIA \\ ** Illinois Institute of Technology. USA
}

Fecha de recepción: 14/ 03/ 2011 Fecha de aceptación: 14/ 07/ 2011

Resumen PAG. 321 - 352

\begin{abstract}
Esta investigación determina las cargas por eje de los camiones que circulan por un puente ubicado en una de las vías principales de Colombia, utilizando la técnica de control BWIM (Bridge Weight in Motion), no empleada antes en el País. Nuestro grupo de investigación implementó la Metodología de los Algoritmos genéticos, instrumentación y monitoreo, para el Puente denominado Boquerón en la vía Bogotá - Villavicencio, Colombia. Para ese fin, se instrumentaron cuatro vigas con un sistema electrónico de medición de tráfico en cada carril, además de un sistema de adquisición de datos y ensayos de laboratorio. Desarrollamos la calibración de su modelo estructural y la generación de funciones matemáticas para hacer converger líneas de influencias de cargas con pruebas experimentales y así determinar las cargas en movimiento de los camiones. En adición, se desarrolló una herramienta computacional, capaz de representar con aceptable precisión las cargas en movimiento.
\end{abstract}

Palabras Clave: Puentes, algoritmo genético, cargas en movimiento, instrumentación, monitoreo, medición de tránsito y modelación estructural

Abstract

This research determines the axle loads of trucks traveling on a bridge located in one of the most important corridors of Colombia, using the technique of control BWIM (Bridge Weight in Motion), not used before in the country. Our research group developed a Genetic Algorithm based in a trial test, implementation and monitoring to the bridge called Boquerón of Colombian Highways (Bogota - Villavicencio). For such an effort, four girders were monitored by data acquisition electronics joined by an electronic traffic log device by lane accompanied of laboratory testing for materials. Model calibration was performed by mathematical approach of in-situ influence lines compared to those obtained by modeling, giving as outcome loads of moving trucks over the bridge. In addition, we developed a computational tool, able to represent with reasonable accuracy the moving loads.

Keywords: Bridges, genetic algorithm, moving loads, instrumentation, monitoring, transit estimation, structural models

\section{Introducción}

\footnotetext{
1 Autor de correspondencia / Corresponding author: E-mail: edgar.munoz@javeriana.edu.co
}

\section{Introduction}

Bridges in the National Road Network of Colombia are the most important structures for the Country; they are mainly old structures lacking of proper maintenance during their operating life and, consequently they are vulnerable to deterioration due to their current conditions. One of the main reasons for such deterioration is overload caused by trucks travelling on trunk roads and cross roads of the network, which accelerates damage phenomena and considerably diminishes their durability. 
The overloads increase has been detected by the National Institute of Roads Network (INVIAS) and Road Concessionaires by means of weighing control stations, static and mobiles, determining trucks overloads ranging from $1 \%$ to $10 \%$ by static weighing stations and, from $4 \%$ to $16 \%$ by mobile stations. Damages caused by surcharge demand an extra investment of resources from the government for rehabilitation purposes, which could be saved if an improved and complementary road-weight control system might be implemented.

One of the research strands in our research team is referred to Bridges Engineering and Structural Reliability and, from five years now, it is related to the statistic study of actual load conditions (weighing system, traffic counting, among others) by employing structural reliability techniques for the evaluation on existing bridges (so far (3) three bridges in the National Road Network have been monitored and implemented thus obtaining relevant outcomes). Particularly, the research project named: Evaluation by structural reliability on steel bridges based on monitoring and instrumentation conducted an instrumented evaluation on Puerto Salgar bridge (located in the Honda - Río Ermitaño highway), Colombia, finding that surcharge due to trucks travelling on the bridge ranges from 10 to $15 \%$. Furthermore, it was proved that design capacity $\mathrm{C40-95}$ in the Colombian Code for Bridges Seismic Design (CCDSP) does not entirely include the surcharge provoked by actual trucks travelling on such structure.

The most critical issue for national engineering is the fact that partial or total collapses have taken place in some vehicular bridges of National Roads Network, where overload is considered as one of the main causes. Such statement is also supported by other researches in the Research Team, particularly by: Collapse Causes of some bridges in Colombia ( $E$, Muñoz, 2002). Consequently, road infrastructure works, both new and old ones, shall have quite clear maintenance schedules to certify their proper working condition, stability and operational lifetime (among them: weighing control of trucks-tractor travelling on main highways). Therefore, it becomes urgent to complement conventional weighing control systems currently available in the Country and to implement new systems providing wide range, higher coverage and, relatively low cost, i.e., economically practical for the national budget. Based on such requirements, this paper proposes a weigh-in motion system to determine the total gross load, load per axle, 
type, counting, among others factors for trucks travelling on a bridge, by means of instrumentation and development of a genetic algorithm for dynamic conditions.

\section{Theoretical framework and state of the art}

Brand new and existing bridges in the National Roads Network in Colombia are designed and reviewed by using the C40-95 truck type, in the Colombian Code for Bridges Seismic Design (CCDSP). Such overload was established by the Colombian Association of Seismic Engineering (AIS) and was confirmed by the National University of Colombia (Bogota Head Office) in 1997 in the research: Definition of design capacity for Bridges in Colombia.

Nowadays, the overloads control and study of trucks-tractor travelling on the National Road Network of Colombia is carried out by means of static weighing and weigh-in motion systems, managed by INVIAS, National Concession Institute (INCO) and Concessionaires.

On the other side, there are two (2) weigh-in motion systems available worldwide, both based on international specifications of Regulation ASTME 131802:

The first is the so called WIM (weight in motion), which consist in measuring static and dynamic strengths on a vehicle axles in motion, thus being able to store data on vehicles weight, traffic volume, classification and speed. Due to its shape and practical installation, it has the advantage of being unnoticed by drivers who do not try to avoid it. It is generally installed behind a toll gate and after detecting an overloaded truck, the latter is addressed to a fixed (static) station, so that the overload is proved and the eventual sanction is taken. This system has been useful to supervise overloaded vehicles trying to avoid the national traffic regulation and, it has been implemented as the result of traffic increase during last decades to provide protection for infrastructure road works, mainly for bridges.

The second weigh-in motion system by means of an instrumented bridge, called BWIM (Bridge Weight in motion), which enables the determination of dynamic weight (total and per axles, among others) for heavy trucks travelling on a bridge, based on its instrumentation and mathematical developments called genetic algorithms. 
This system provides information on the impact value, lateral distribution factor and stress recordings employed for an additional bridge analysis. It can be adjusted to obtain the same application as from WIM system, with a reasonable accuracy and advantages such as: portability and cost-effectiveness, easy installation and simple maintenance program. The BWIN was created and employed in the world in the 70's by the federal highway administration of the United States (FHWA), previously named B-WIM. On the other hand, Moses (1979) introduced an algorithm to determine live load on an instrumented bridge by using the method of influence lines. In the 80's, the B-WIM system was developed, which was named AXWAY in Australia and, it was based on the same concept of influence lines. Additionally, in 1986 a new system was developed counting with higher effectiveness by employing sewages, which was named CULWAY. Similarly, in the United States, Bridge Weighing Systems Inc. developed one of the first B-WIM commercial systems in 1989, based on genetic algorithms by Moses. In the 90's, three new systems were developed in Ireland, Slovenia and Japan. In Europe, this system was widely used as from 1999, when significant improvements were achieved by recent researchers (See [Quilligan, M, 2003). Nowadays, in the world new dynamic algorithms are under research for this system by employing optimization techniques aimed to improve its performance, accuracy and reliability. In Slovenia this system was used, mainly for the elaboration of a regulation to evaluate load capacity for existing bridges (Znidaric, Jas, 1994).

Genetic Algorithms, according to Goldberg (1989), are algorithms-in-search widely used to solve problems or to achieve partial optimization solutions. These algorithms are developed from a set of possible solutions for a given problem, which are progressively improving by means of evolutionary simulation processes, that include natural selection and genetic information exchanges the same as in a natural evolution process (which is referred as genetic in structural analysis). One of the main characteristics of such procedures is the fact that they work on a solution population; not only for one kind of solution, as traditional procedures do. Genetic algorithms enable the exploration of different regions of a solutions space at the same time, therefore the chances of getting limited to a local minimum space is reduced. 
According to [Quilligan, $M, 2003$ ] different genetic algorithms methods are under study for the evaluation of live loads, which are based on different aspects and criteria such as: lines of influence, advanced structural models on fine elements, influence surfaces on finite element models, among others. Also based on advanced numerical simulations, which include a multiple flow of vehicles and dynamic algorithms developed by [Chan et. al., 2006], [Law et. al., 1997], [Zhu et. al., 2000], among others.

National experience on the subject

The B-WIM system has not been implemented in Colombia either by INVIAS or by INCO, Concessionaires or Universities. However, a PhD thesis work developed at Pontificia Universidad Javeriana (Acevedo, A. et el al. 2006), studied the system by means of a prototype to scale on Puerto Salgar bridge (see Figure 1), thus becoming the first local experience on this subject. It was based on simulations and laboratory tests including the development of a genetic algorithm and the prototype instrumentation, thus achieving significant outcomes used as data input for this project and future related research studies.

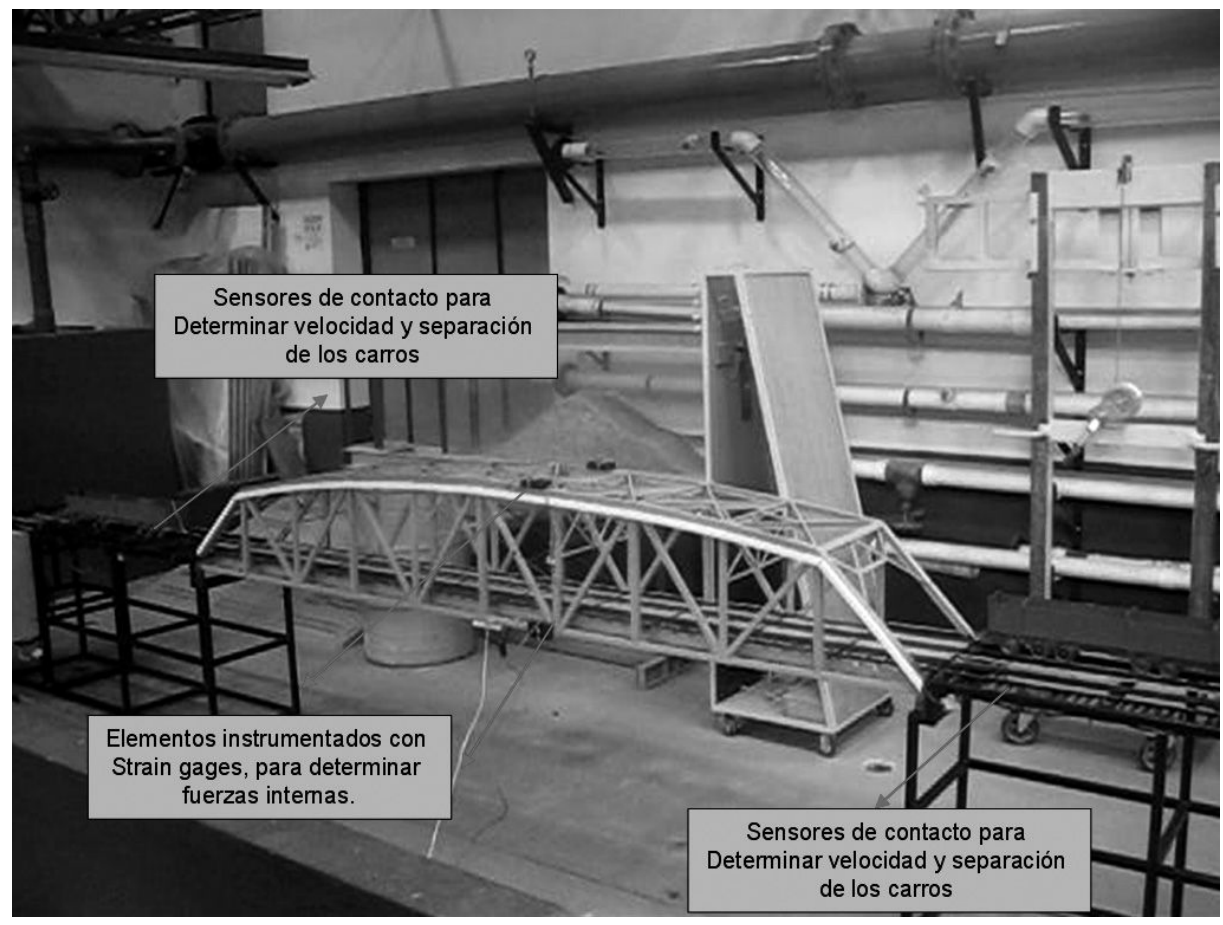

Figura 1. Prototipo a escala del puente Puerto Salgar, con su respectivo sistema de instrumentación Figure 1. Prototype to scale on Puerto Salgar Bridge with its instrumentation system 


\section{Methodology}

Following a detailed description of each stage implemented for the execution of this research project.

3.1. Selección del puente y recopilación de información

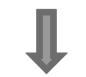

3.2.1 Sistema de medición del tráfico

3.2. Diseño e implementación del sistema de instrumentación y monitoreo en el puente

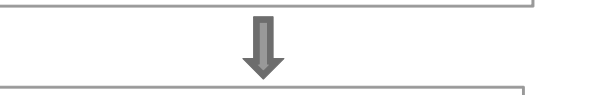

\section{.}

3.3. Medición de tránsito

\subsubsection{Instrumentación de las vigas}

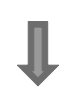

3.4 Desarrollo y calibración de algoritmo genético

Figura 2. Etapas del estudio

Figure 2. Research Study Stages

3.1 Bridge selection and data collection

This stage consisted in the selection of a vehicular bridge which was adapted for the implementation of a weigh-in motion system, so that the bridge would meet the following requirements: being a single-span structure, being part of a main road with no horizontal curves and, having a pavement surface in good conditions. For such an effort, our "Structures" research team contacted COVIANDES Concessionaire that administrates Bogota - Villavicencio highway, Colombia, to introduce the research project scope and they decided to authorize the implementation on Boquerón Bridge. The structure of this bridge is composed of post-tensioned beams; reinforced concrete slab, simple bearing slab; 20 meters span (between axles); deck 14.50 meters wide (see Figure 3 and Figure 4). 


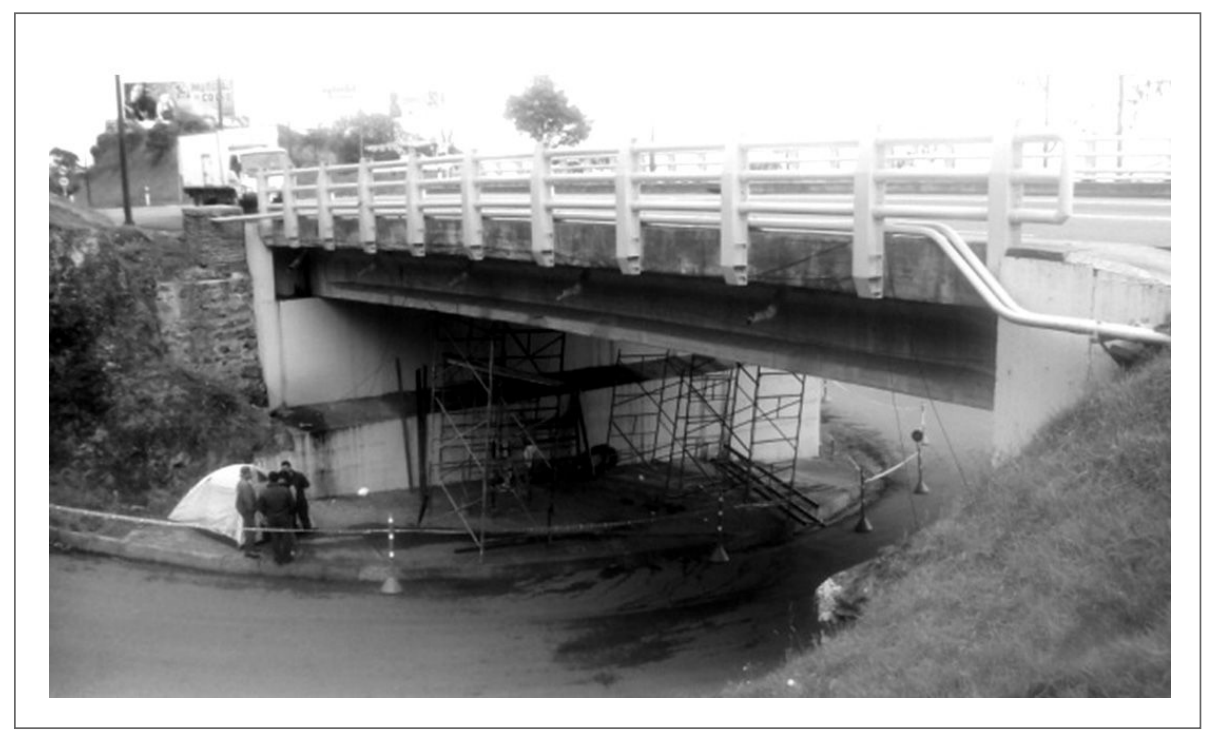

Figura 3. Vista en perfil del puente Boquerón simplemente apoyado de viga postensada y losa en concreto reforzado Figure 3. Cross section view for Boquerón Bridge, which is simply supported by a post-tensioned beam and reinforced concrete slab

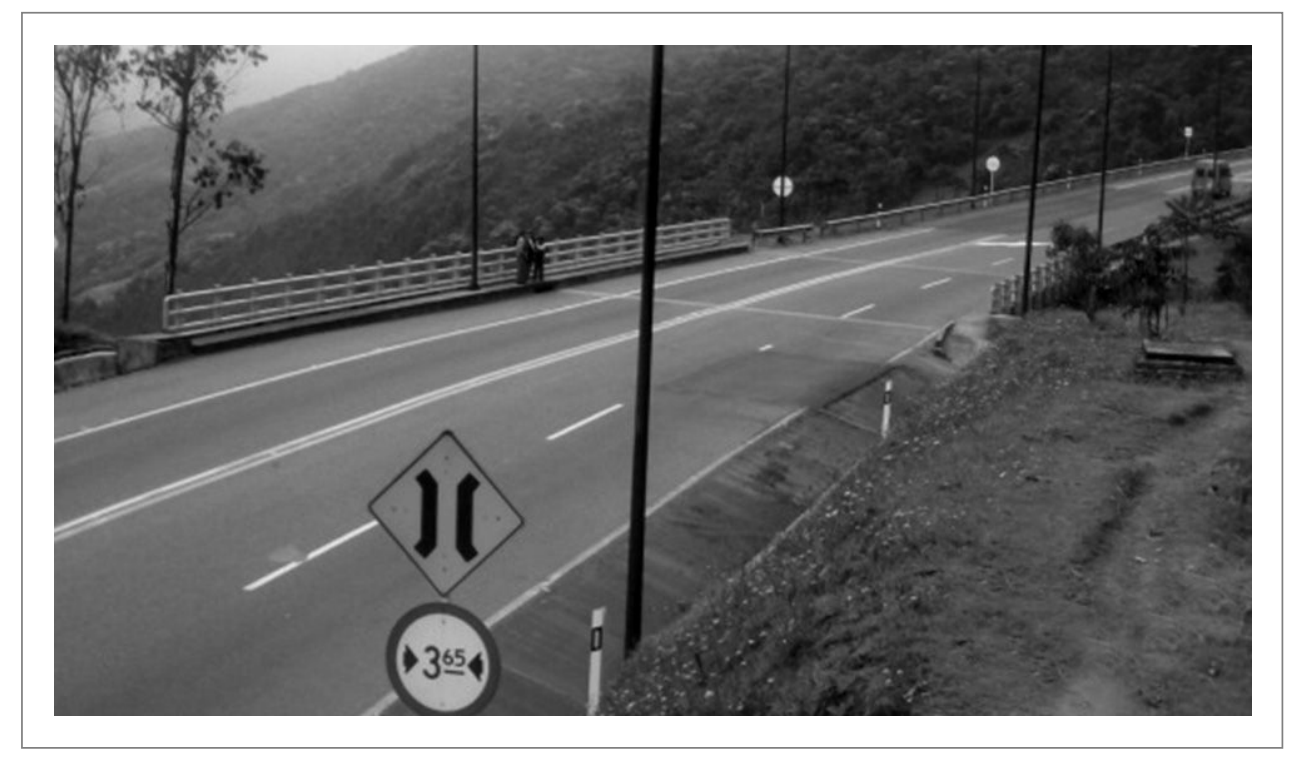

Figura 4. Vista en planta del puente Boquerón

Figure 4. Plan view on Boquerón Bridge

Additionally, for this research work, COVIANDES Concessionaire delivered construction drawings and logistic support for instrumentation and monitoring tasks on this bridge. Besides for information about traffic features crossing the bridge, the company also provided load per axle records of trucks travelling on the Bogota-Villavicencio Highway, on the very same dates when instrumentation was carried out. 
3.2. Design and implementation of instrumental and monitoring system on the bridge

This field task was divided into (2) stages which are detailed below:

\subsubsection{Traffic measurement system}

For this stage, the research group purchased the TRS System manufactured by Canadian Company IRD International Road Dynamics Inc., which provides realtime information on: speed, axle number, distances between axles for any kind of vehicle travelling on each bridge's carriageway (See Figure 6). For installation and start up, the local company CONTELEC was hired, who are specialists in the adjustment of static weighing systems and weigh-in motion systems (manufactured by IRD). Pavement cutting were developed, two (2) inductive loops and (4) piezoelectric wires were embedded inside each carriage way, as observed in Figure 5 and Figure 7.

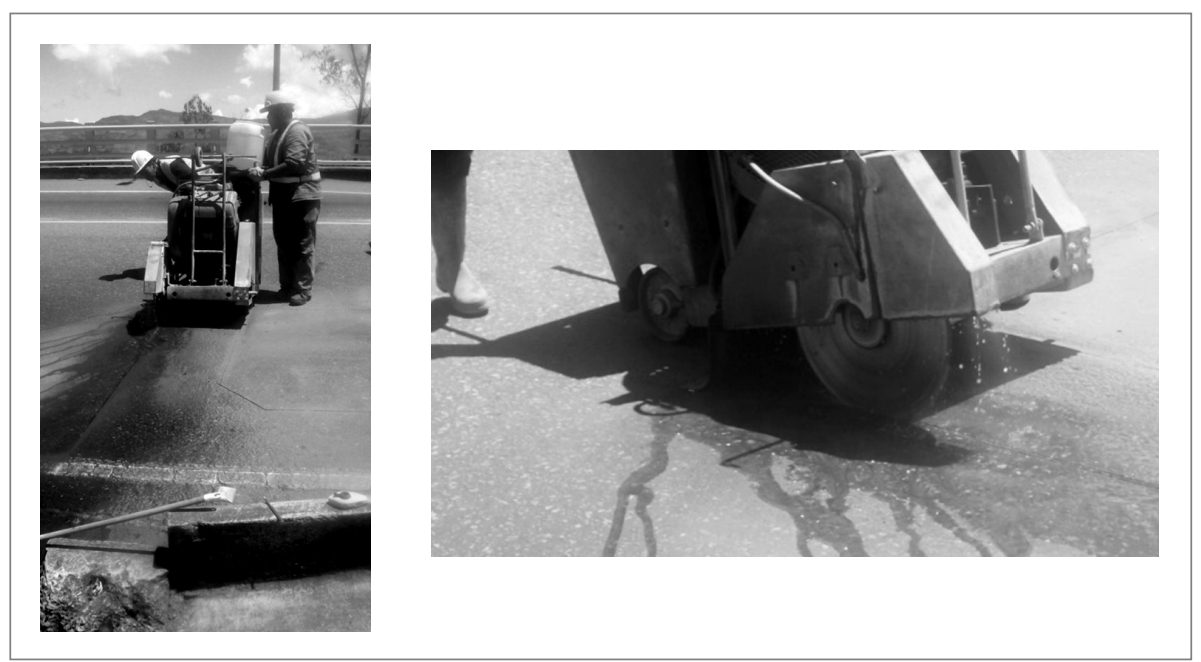

Figura 5. Cortes en el pavimento para la instalación de los Loop inductivos y cables piezoeléctricos Figure 5. Pavement cutting for the installation of inductive loop and piezoelectric wires

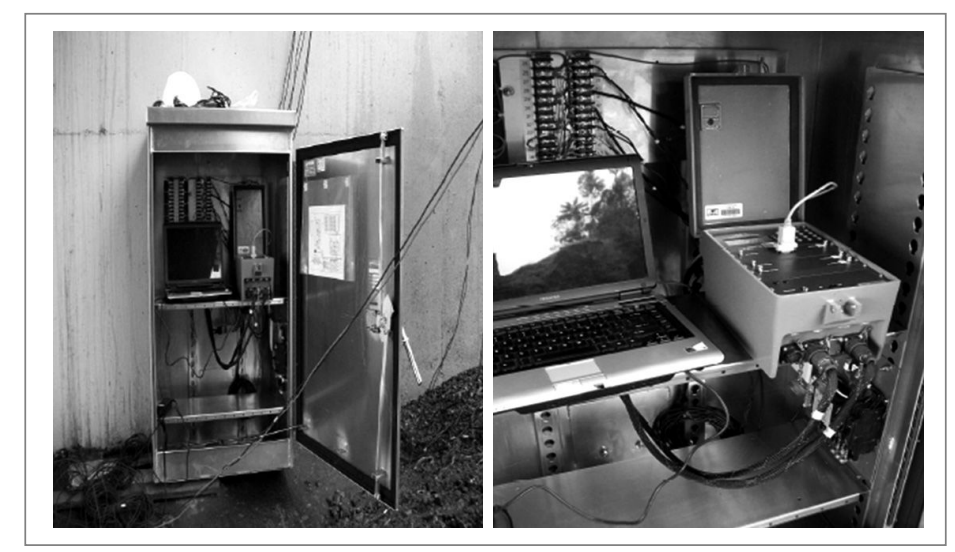

Figura 6. Gabinete con las conexiones electrónicas, el sistema suministrado por la empresa Canadiense IRD - International Road Dynamics Inc. y un computador para la adquisición de los datos de conteos y medición de los vehículos que circulan por el puente.

Figure 6. Electric connection cabinet of the system supplied by Canadian IRD - International Roads Dynamics Inc; computer for data collection of counting and measurements on vehicles travelling on the bridge 


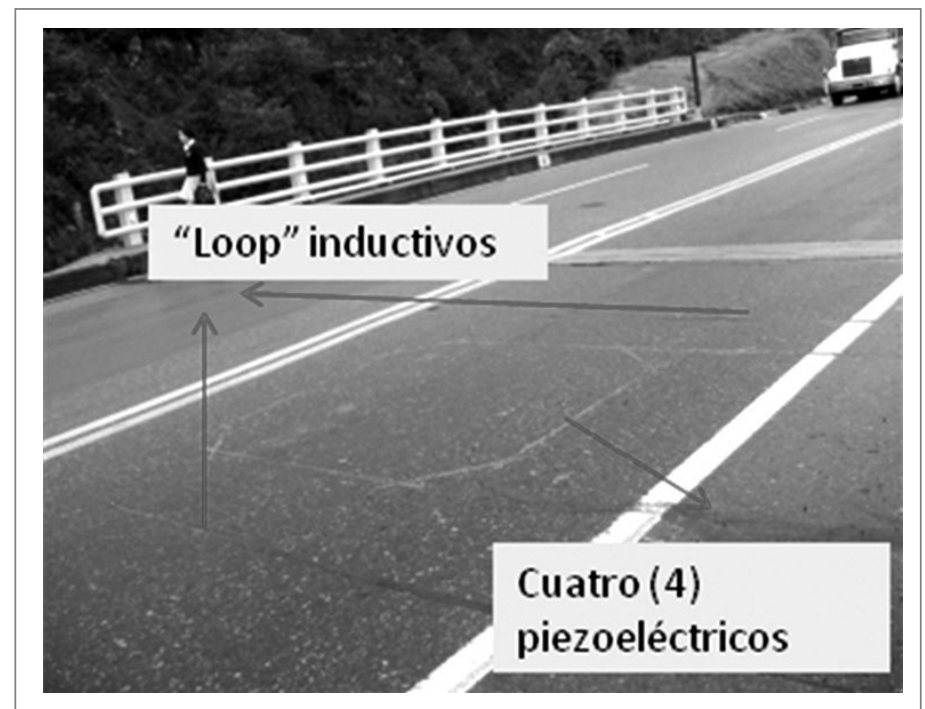

Figura 7. Dos (2) Loop inductivos y cuatro (4) piezoeléctricos instalados en la calzada Bogotá - Villavicencio Figure 7. Two (2) Inductive loops and four (4) piezoelectric wires installed in the Bogota-Villavicencio carriageway

\subsubsection{Beams Instrumentation}

Four (4) out of the five pre-stressed bridge beams were instrumented by means of a LVDT installation, which enabled the measurement of vertical displacements on real time, synchronized with the traffic measurement system explained above. For such an effort, screed rails were supported on scaffoldings which allowed the vertical installation of LVDT at the bridge mid-span, as observed in Figure 8 and 9.

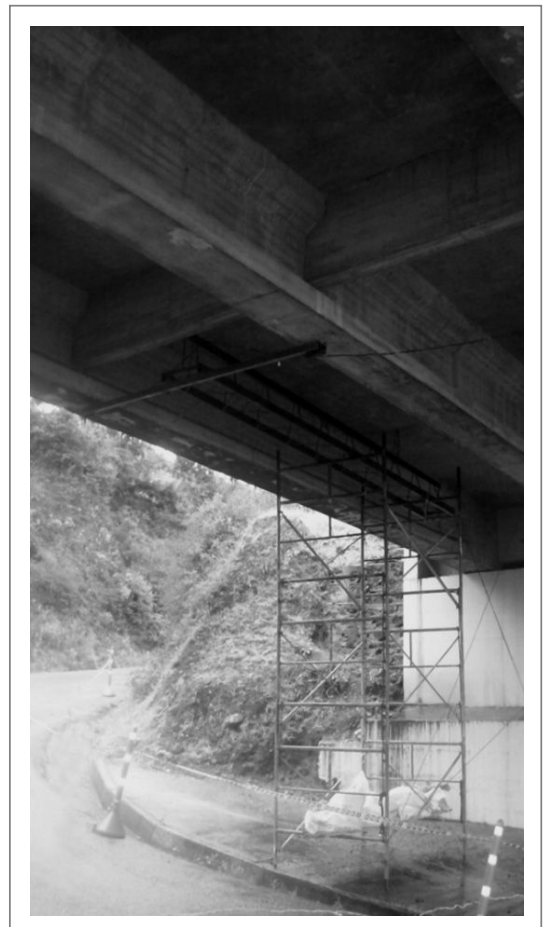

Figura 8. Instalación de los LVDT en el centro de las cuatro vigas preesforzadas principales del puente que permiten medir deformaciones verticales por el paso del tráfico sobre el puente

Figura 8. LVDT installation in the center of the main four pre-stressed beams, which allow the measurement of vertical deformations due to the traffic travelling on the bridge 


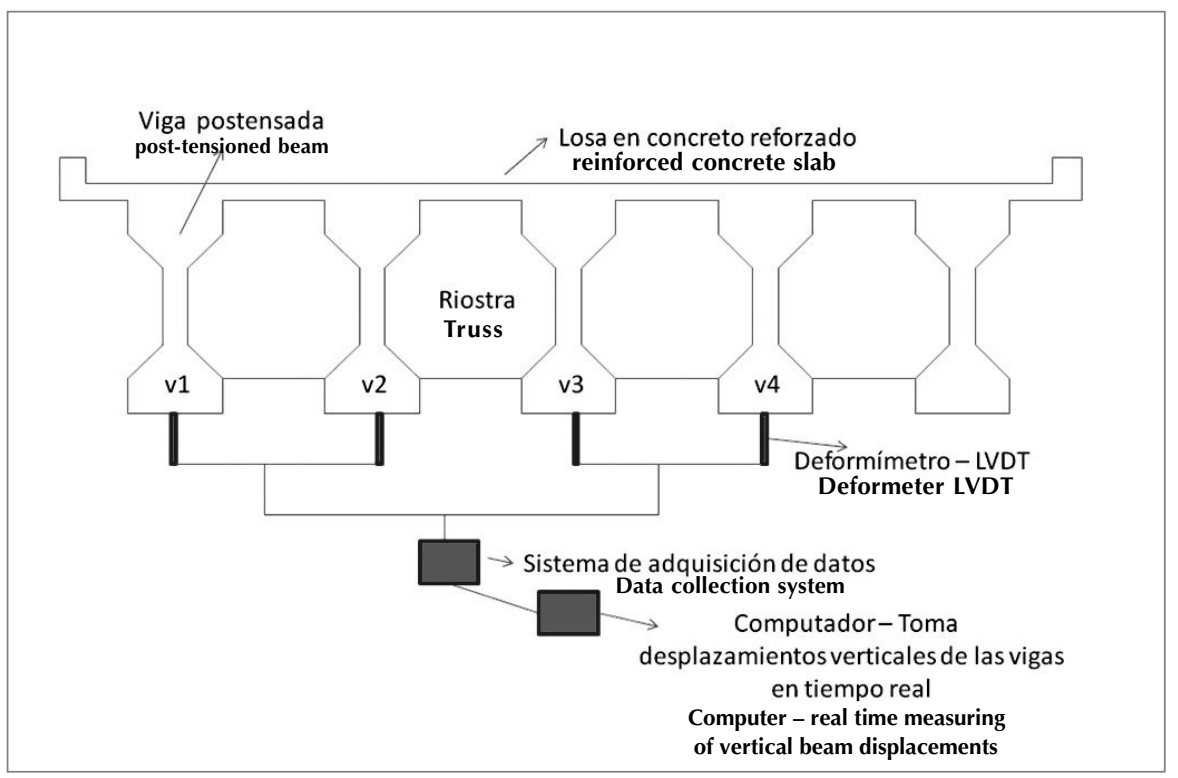

Figura 9. Esquema con la localización de los LVDT en las vigas del puente y el sistema de toma de datos Figure 9. Layout of LVDT allocation on bridge beams and, data collection system

\subsection{Traffic measurement}

Another application from the instrumentation system is the automatic measurement of differentiated traffic travelling on the carriage way. By comparing the obtained results to the traffic volumes presented by INVIAS, the accuracy of the device measuring traffic is confirmed, thus generating a great research potential from traffic and transportation engineering point of view.

Trucks TDP obtained from the current pilot test was 5858; trucks TDP reported by INVIAS for year 2008 was 5153 , which with a moderate growth could achieve approximately from 5500 to 5800 for year 2010; thus demonstrating the soundness of automatic traffic measurements by means of installed ground sensors. From comparative analysis of percentage distribution obtained from pilot test and the one provided by INVIAS a great similarity is found. The pilot test of the current research delivered weights percentage distribution of $76 \%, 5 \%$, $11 \%$ and $8 \%$, for $\mathrm{C} 2, \mathrm{C} 3-4, \mathrm{C} 5$ and $>\mathrm{C} 5$; the volumes delivered by INVIAS have weights percent distribution of $64 \%, 10 \%, 10 \%$ and $16 \%$, for C2, C3-4, C5 and >C5, respectively. On the other hand, the pilot test also enabled gathering information about vehicles speed on a sound basis. 
3.4. Development and calibration of genetic algorithm The stages carried out to develop a genetic algorithm are presented below, by means of a computer application implemented in MATLAB. It is able to estimate load per trucks axles sensed by the electronic system explained in number 3.2.1, so that it can approximate to magnitude vertical deformations undergone by four (4) beams instrumented by means of electronic systems explained in number 2.3.2 (See figure 10).

\subsubsection{Model Structural Development}

Based on the bridge's design drawings, a structural model was developed for its deck, which is a "grillage" or "full framed" deck type that is composed by discrete finite elements of frame re-bar or frame in SAP2000 software. This model contains geometrical properties of aforementioned slab elements (See Figure 11), such as: structure beams, slabs, trusses and kerbs.

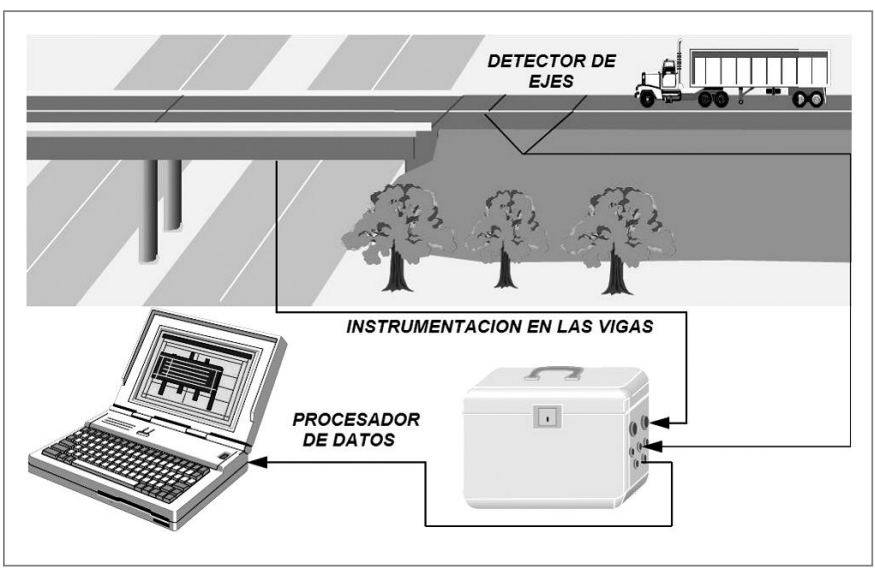

Figura 10. Esquema del sistema de pesaje en movimiento de puentes (Tomado de Znidaric, et al.) Figura 10. Scheme of weigh-in motion system on bridges (reference from Znidaric, et.al)

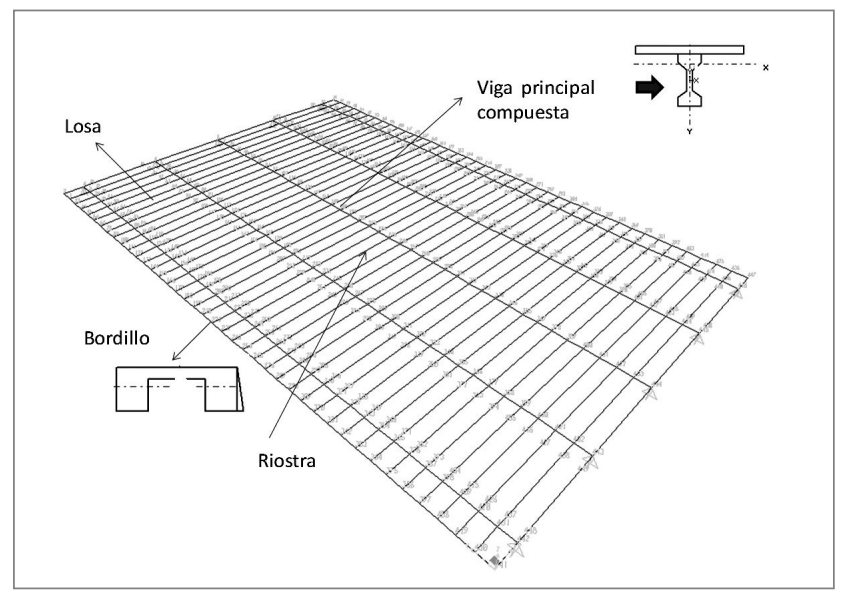

Figura 11. Modelo estructural del tablero del puente desarrollado en SAP-2000

Figure 11. Structural model for the bridge deck developed by SAP-2000 


\subsubsection{Calibration of structural model}

So as to calibrate the structural model of the bridge deck and its corresponding stiffness matrix, the following stages were carried out.

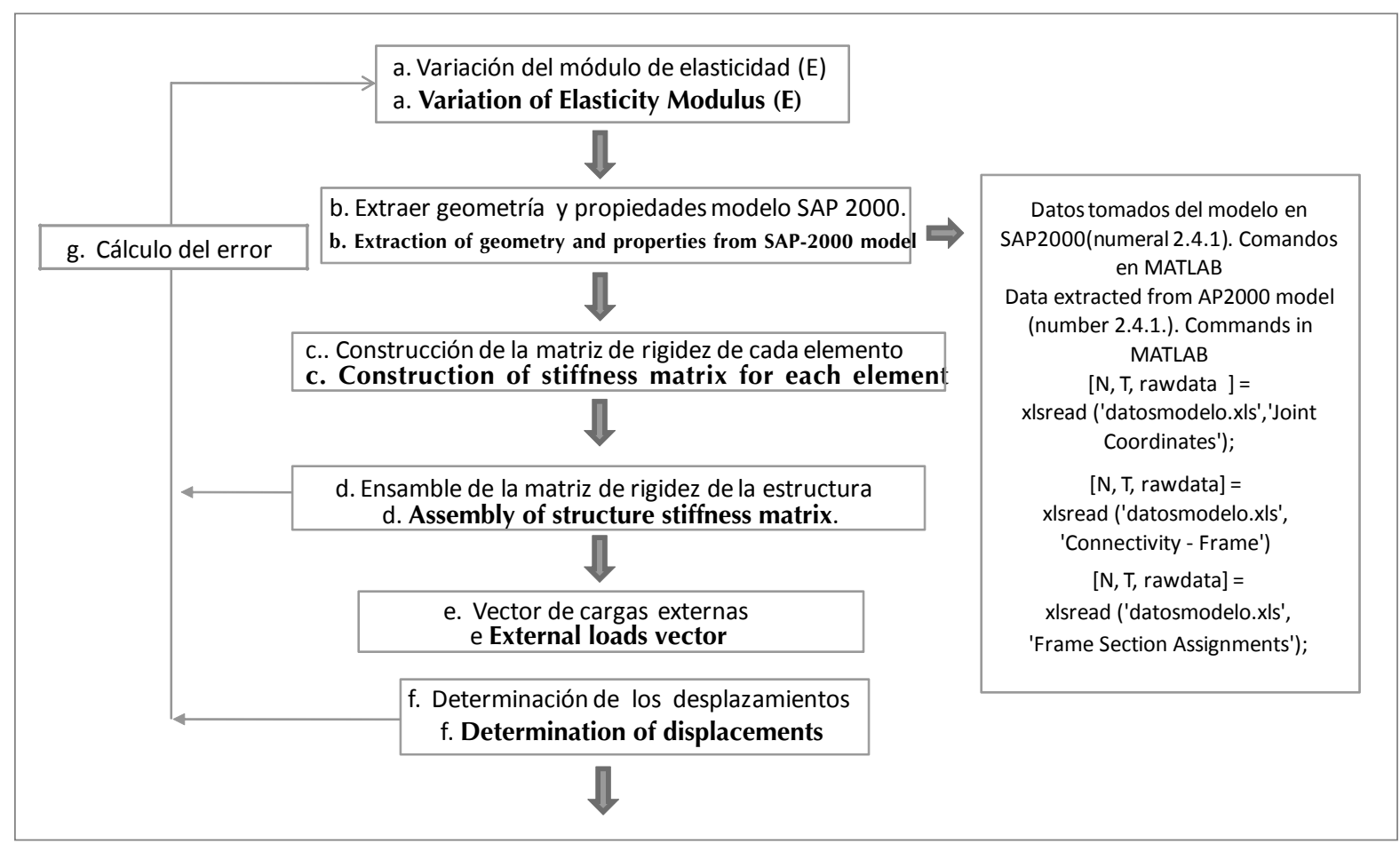

Figura 12. Procedimiento de calibración de modelo estructural de puente

Figure 12. Calibration process for the bridge structural model

a) Variation of elasticity modulus: The elasticity modulus of concrete bridge deck was investigated by means of the extraction or four (4) cores as observed in

b) Figure 8 and Figure 13. Such cores were tested by the universal machine at materials laboratory in the Civil Engineering Department of the Pontificia Universidad Javeriana, finding that they have a standard variation and variation coefficient of $14143.8 \mathrm{Mpa}(141,438$ $\mathrm{Kg} / \mathrm{cm} 2$ ) and $39 \%$, respectively. Those are quite high values that may be caused by concrete quality variations during the bridge constructive processes. Such modulus ranges from 27,076 to $62,026 \mathrm{Mpa}(270,760$ to 620,260 $\mathrm{Kg} / \mathrm{cm} 2)$ and have an average variation of $35,636.5$ Mpa $(356,365 \mathrm{Kg} / \mathrm{cm} 2)$. For the calibration of structural model, such characteristic statistics and variations were used. 


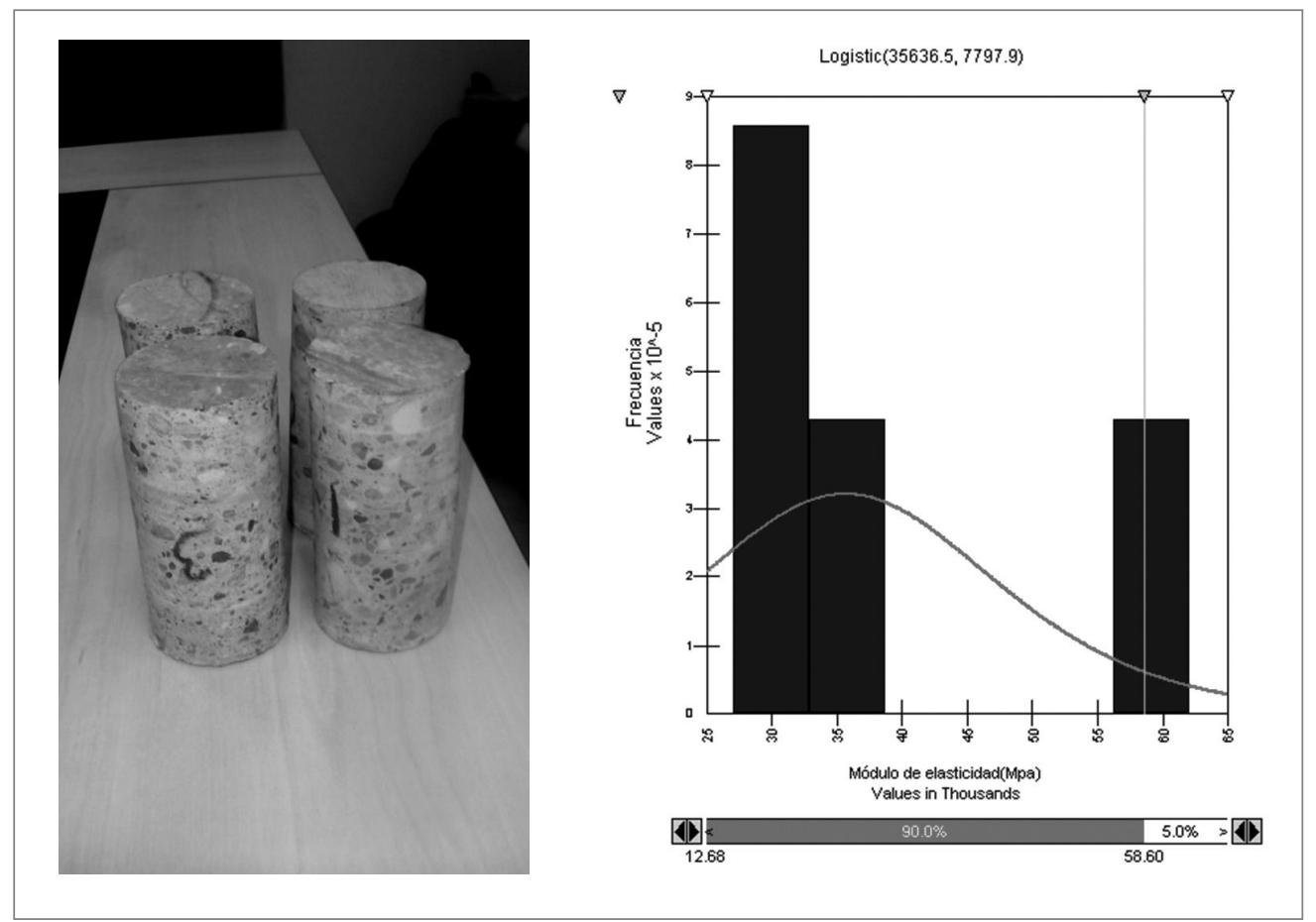

Figura 13. (a) Núcleos extraídos de la vigas del puente para la evaluación del modulo de elasticidad. (b) Curva de probabilidad del módulo de elasticidad del concreto

Figura 13. (a) Cores extracted from deck beams for the evaluation of elasticity modulus.

(b) Probability curve for concrete elasticity modulus

c) Geometry and properties of SAP-2000 model. The software application developed in MATLAB was designed to collect data on SAP-2000 structural model and being able to work on calibration processes and genetic algorithm only in the MATLAB application (Figure 14). The information collected is:

- Number of nudes and coordinates in nudes spaces $(x, y, z)$

- Number of elements and the incidence of each one of them

- Geometrical properties of each element

- Number and identification of degrees of freedom and restricted degrees.
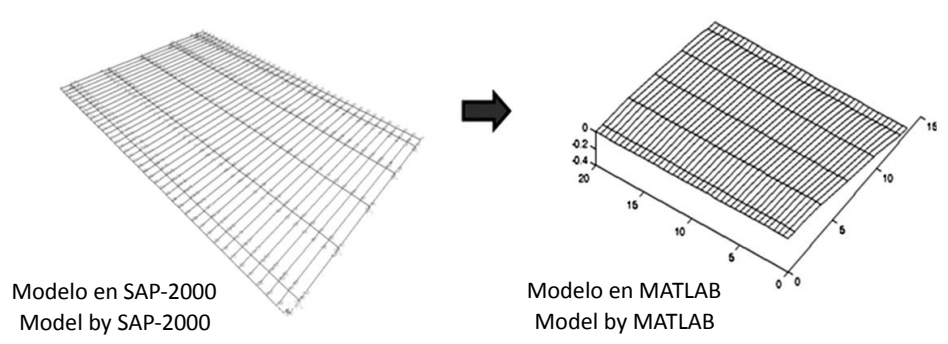

Figura 14. Transferencia de datos del modelo estructural en SAP-2000 al aplicativo computacional en MATLAB Figure 14. Data-transfer from SAP-2000 structural model into MATLAB software application 
d) Construction of global stiffness matrix for each element: For this research, it was decided to work on a space stiffness matrix, which has six degrees of freedom per node (three displacements and three rotations). Equation (1) shows a local stiffness matrix for the element "rebar" type, which turns into a global stiffness matrix by using equations (2), (3) and (4) shown below.

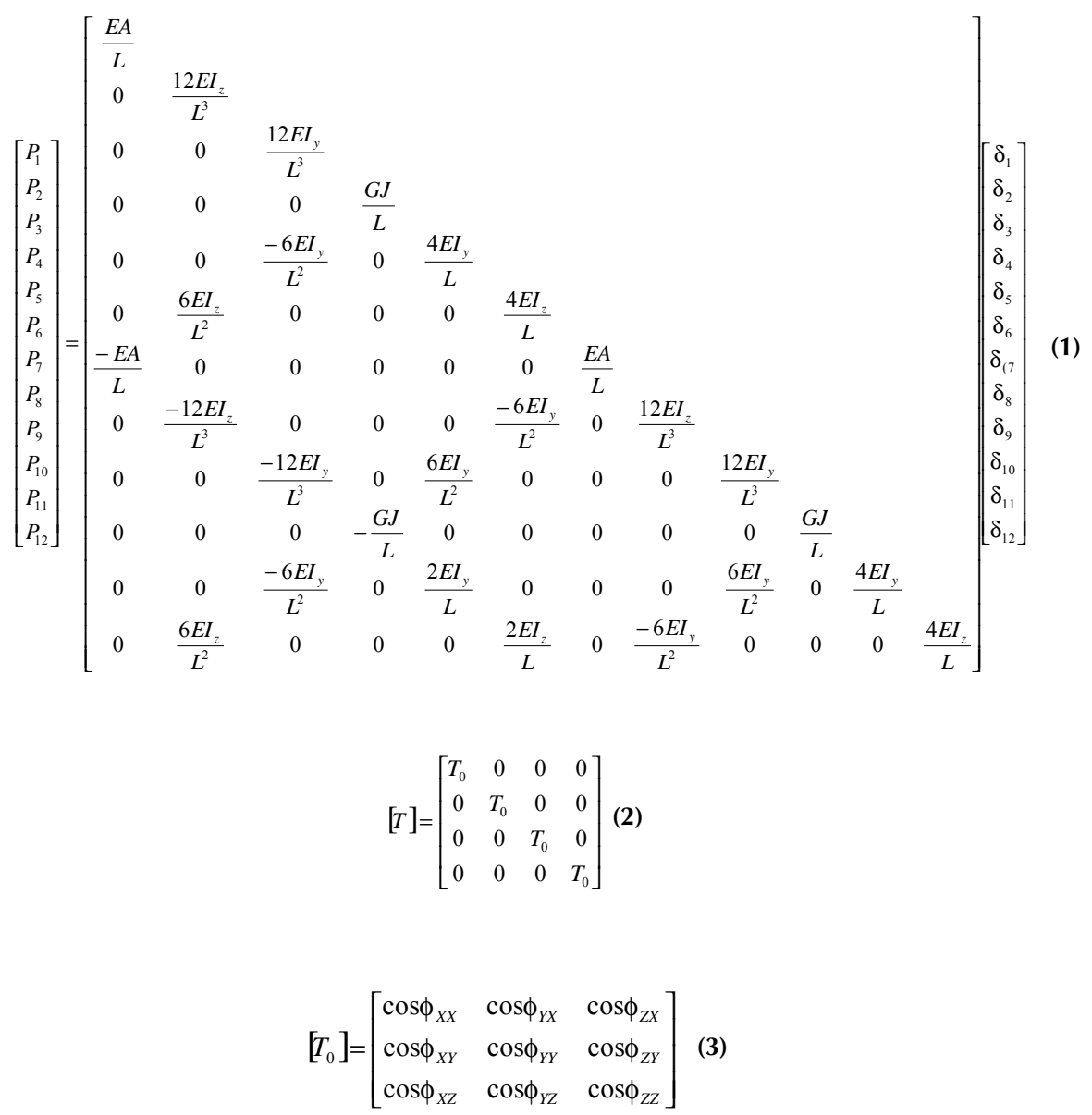

$[$ Kgloba $]=[T][$ Klocal $][T]$ 
e) Assembly of structure stiffness matrix. Based on stiffness results for each element, the structural model matrix is determined by means of an assembly mathematical process developed in MATLAB.

f) External loads vector: The software is able to build up a vector from available loads per axle on heavy trucks (obtained from static and dynamic load tests), taking into account location and the corresponding application of nodes, by considering trucks geometry (See Figure 15). This sub-routine was designed so as to generate a vector for dynamic load or moving load travelling on a carriage way or (2) double carriage way.

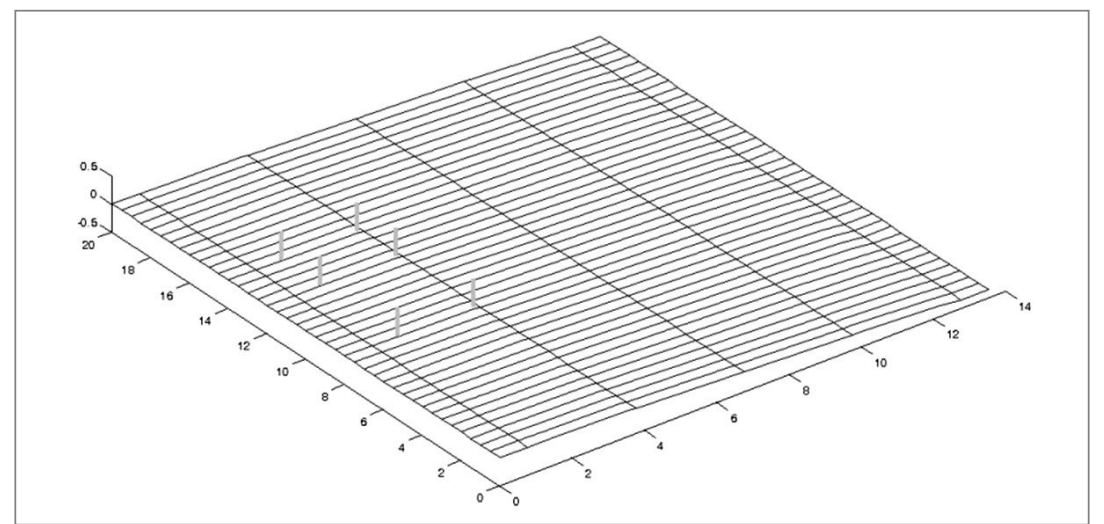

Figura 15. Aplicativo computacional en MATLAB de modelo estructural con una hipótesis de carga, cuyos datos se construyen en un vector

Figure 15. MATLAB application software for the structural model with a hypothetical load, which data turn into a vector

g Determination of displacements: By employing the method of matrix analysis, values were achieved for each static load test and from calibration process theoretical vertical displacements at mid-beams $\mathrm{V} 1$, V2, V3 and V4 were achieved.

h) Calibration of error calculation: Determination of errors based on the comparison results between beams displacements V1, V2, V3 and V4, both experimental and theoretical, as expressed below:

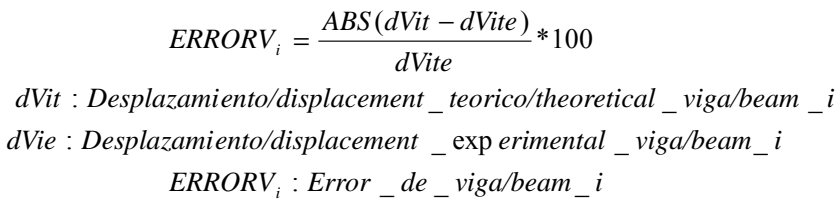


The average cumulative error, taking into account the combination of individual error in each beam, was determined as follows:

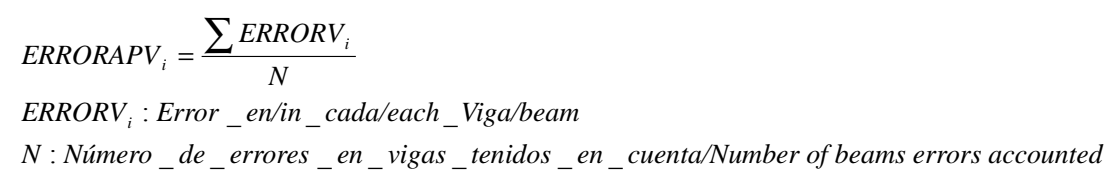

From above process different analytical solution alternatives were obtained, which allowed the selection of the lowest error and most reliable alternative for the bridge real behavior. One in-situ static test was developed by placing a C3 truck (supplied by the concessionaire) on a bridge lane, which geometry and loads per axle were previously known. This truck produced vertical displacements recorded by monitoring equipment, which location and magnitude is observed in Figure $\mathbf{1 6 .}$

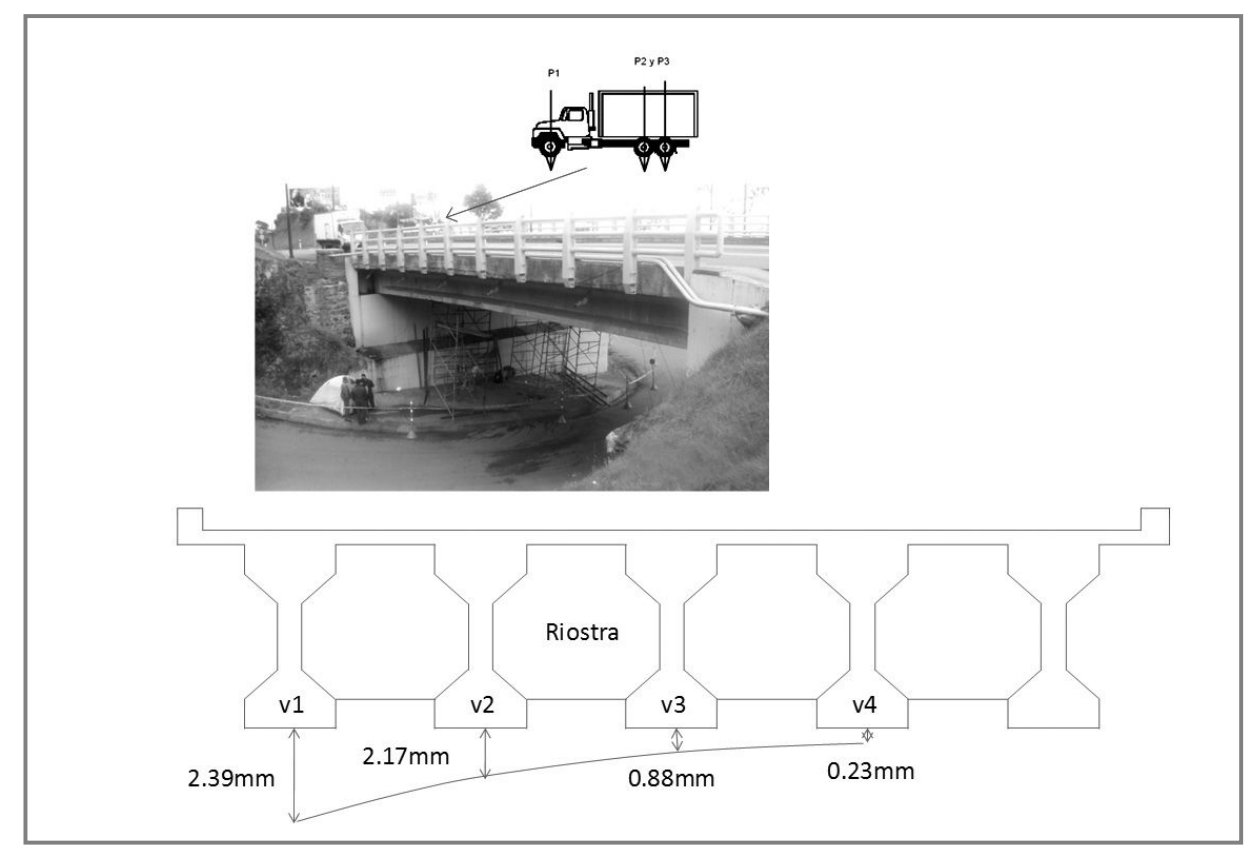

Figura 16. Prueba estática del camión C3 sobre un carril del puente Villavicencio-Bogotá, previamente pesado. Deformaciones registradas en la instrumentación

Figura 16. Static test on $\mathrm{C} 3$ truck placed on a Villavicencio-Bogota Bridge lane, previously weighed. Deformations recorded by instruments

Based on the static test and by using the information from abovementioned stages (See Figure 12), the following results were obtained for each test: 
Puente basado en algoritmos genéticos e instrumentación/Bridge based on genetic algorithms and instrumentation

\begin{tabular}{|c|c|c|c|}
\hline $\begin{array}{l}\text { Número de prueba } \\
\text { Number of Tests }\end{array}$ & $\begin{array}{c}\text { Módulo de elasticidad (ton/mm2) } \\
\text { Elasticity Modulus }\end{array}$ & $\begin{array}{l}\text { Error acumulado promedio(\%) } \\
\text { average cumulative error }\end{array}$ & Comentario/Commentary \\
\hline 1 & 4.36 & 8.355 & $\begin{array}{l}\text { Rigidez de las vigas } 2,3 \text { y } 4 \text { sin aumentar. Considerando } \\
\text { los errores de las vigas V1, V2, V3 y V4 } \\
\text { Beams stiffness 2, 3, and 4, without increases. Considering } \\
\text { beams errors V1, V2; V3 and V4 }\end{array}$ \\
\hline 2 & 4.36 & 7.3525 & $\begin{array}{l}\text { Disminución de la rigidez de las vigas } 2,3 \text { y } 4 \text { en un } 5 \% \\
\text { hasta } 0.1507 \mathrm{~m} 4 \text {. Considerando los errores de las vigas } \\
\text { V1, V2, V3 y } \mathrm{V} \\
\text { Decrease of beams stiffness } 2,3 \text { and } 4 \text { in } 5 \% \text { up to } 0.1507 \\
\text { m4. Considering beam errors } \mathrm{V} 1, \mathrm{~V} 2 ; \mathrm{V} 3 \text { and } \mathrm{V} 4\end{array}$ \\
\hline 3 & 4.4 & 6.83 & $\begin{array}{l}\text { Disminución de la rigidez de las vigas } 2,3 \text { y } 4 \text { en un } 5 \% \\
\text { hasta } 0.1507 \mathrm{~m} 4 \text {. Variación del módulo de elasticidad } \\
\text { hasta detectar } \mathrm{E}=4.4 \mathrm{Ton} / \mathrm{mm} 2 \text {-Considerando los errores } \\
\text { de las vigas } \mathrm{V} 1, \mathrm{~V} 2, \mathrm{~V} 3 \text { y } \mathrm{V4} \\
\text { Decrease of beams stiffness } 2,3 \text { and } 4 \text { in } 5 \% \text { up to } 0.15704 \\
\mathrm{~m} 4 \text {. Variation of elasticity modulus until detecting } \mathrm{E}=4.4 \\
\text { Ton/mm2. Considering beams errors } \mathrm{V} 1, \mathrm{~V} 2 ; \mathrm{V} 3 \text { and } \mathrm{V} 4 \text {. }\end{array}$ \\
\hline 4 & 4.4 & 8.145 & $\begin{array}{l}\text { Disminución de la rigidez de las vigas } 2,3 \text { y } 4 \text { en un } 5 \% \\
\text { hasta } 0.1507 \mathrm{~m} 4 \text {, aumento de la rigidez de las vigas } 1 \text { y } \\
4 \text { hasta } 0.1613 \mathrm{~m} 4 \text {. Considerando los errores de las vigas } \\
\mathrm{V} 1, \mathrm{~V} 2, \mathrm{~V} 3 \mathrm{y} \mathrm{V} \\
\text { Decrease of beams stiffness } 2,3 \text { and } 4 \text { in } 5 \% \text { up to } 0.15704 \\
\mathrm{~m} 4 \text {. Increase of beams stiffness } 1 \text { and } 4 \text { up to } 0.1613 \mathrm{~m} 4 \text {. } \\
\text { Considering beams errors V1, V2; V3 and V4. }\end{array}$ \\
\hline 5 & 4.4 & 4.65 & $\begin{array}{l}\text { Desplazando las cargas del camión } C 310 \mathrm{~cm} \text { más cerca } \\
\text { de la viga V2, comparando con las anteriores pruebas. } \\
\text { Inercia de las vigas } V 2, V 3 \text { y } V 4 \text { de } 0.1586 \mathrm{~m} 4 \text { y módulo } \\
\text { de elasticidad de } 4.4 \mathrm{Ton} / \mathrm{mm} 2 \\
\text { Displacement of loads on C3 truck, } 10 \mathrm{~cm} \text { close to beam } \\
\mathrm{V} 2 \text { in comparison to previous tests. Beams inertia } V 2 \text {, } \\
\mathrm{V} 3 \text { and } V 4 \text { of } 0.1586 \mathrm{~m} 4 \text { and elasticity modulus of } 4.4 \\
\text { Ton/mm2. }\end{array}$ \\
\hline
\end{tabular}

Nota: En la prueba 3, los errores de cada viga fueon $1.2 \%, 14.24 \%$ y $0.12 \%$ respectivamente.

Note: Test Nr. 3 delivered beams errors of $1.2 \%, 14.24 \%, 11.74$ and $0.12 \%$, respectively)

Figura 17. Tipos de pruebas de calibración realizadas

Figure 17. Type of developed calibration tests

After completing the analysis on different tests, it was concluded that test number 5 is the closest to the bridge real behavior, which delivered a calibrated stiffness matrix of $2676 \times 2676$ having an elasticity modulus of 44.000 Mpa (440.000 Kg/cm2), which was used to develop a genetic algorithm (See Figure 18).

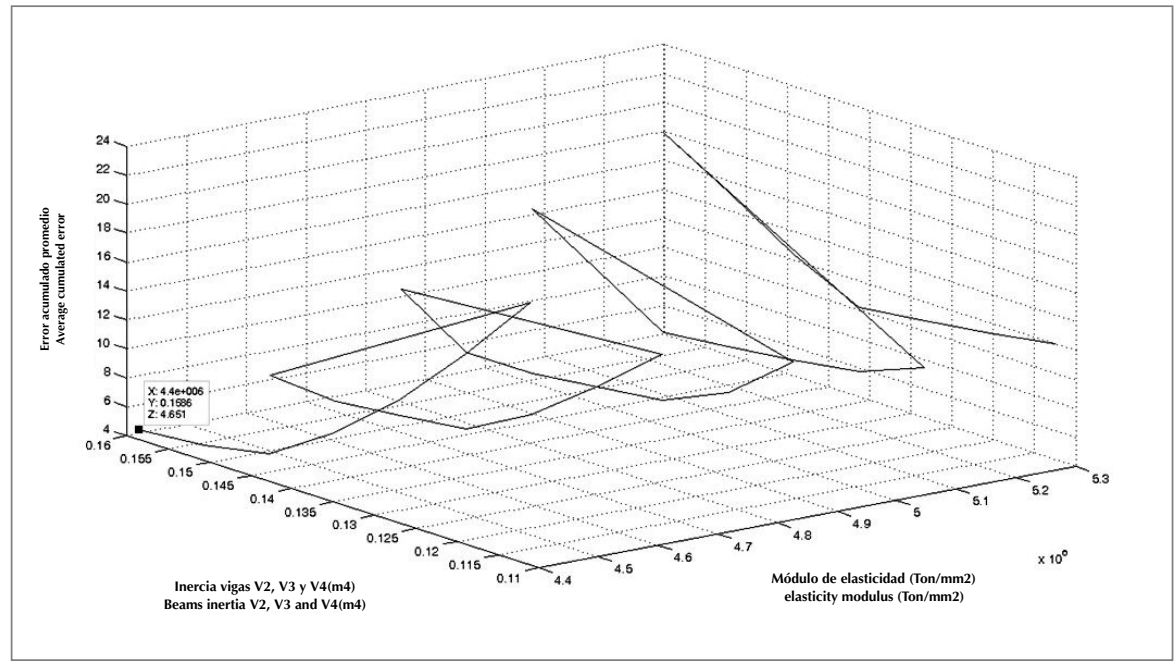

Figura 18. Resultados de la prueba de calibración número 5

Figure 18. Results from calibration test number 5 
3.4.3 Fundamentals and validation of genetic algorithm By using above mentioned results a genetic algorithm was implemented, which enables the estimation of loads per axle travelling on the bridge by employing the following procedure:

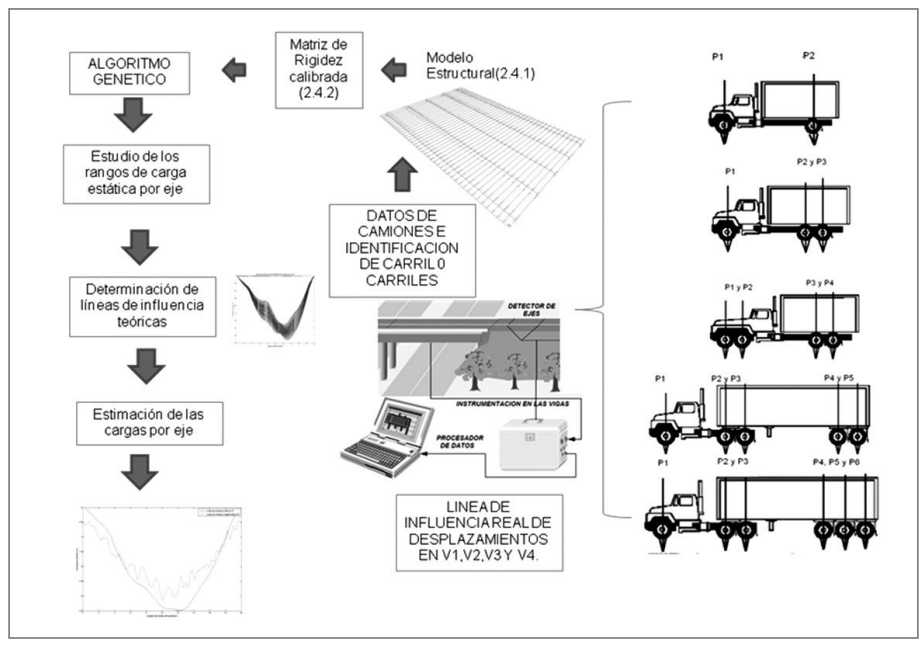

Figura 19. Procedimiento para la determinación de las cargas por eje y total de los camiones que circulan por el puente Figura 19. Procedure for the determination load per axle and total loads of trucks travelling on the bridge

a) Ranges study on static load per axle. The Concessionaire provided a weight record of trucks that travelled on the bridge on the dates the bridge was instrumented. The information enabled an analysis of statistical characteristics for each axle on different trucks, thus determining load ranges to be included in the algorithm design (See Table 1).

Tabla 1. Variación de los pesos por eje de diferentes tipos de camiones Table 1. Variation of weights per axle in different trucks types

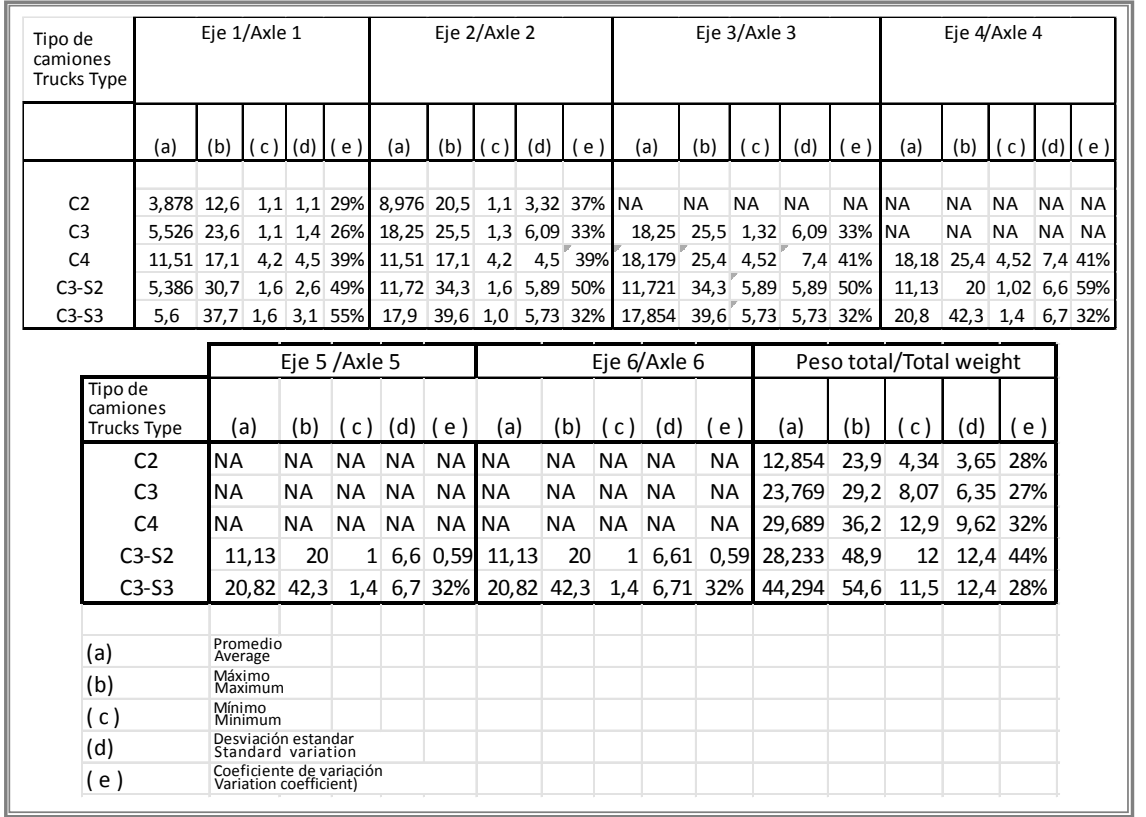


b) Determination of theoretical lines of influence. $A$ software application developed in MATLAB enables the determination of influence lines on vertical displacement at the mid-span on beams V1, V2, V3 and $\mathrm{V} 4$ provoked by a truck travelling on any lane. In other words, the application is able to simulate the passing of any truck type by varying the magnitude of loads per axle by means on an interactive process. A simulation used for the execution and validation of this algorithm was the passing of a C3-S3 truck, which geometry, weight per axle and total weight were consulted. The space between axles and speed were obtained by means of a traffic measurement device explained in number 2.3.1. Figure 20 shows some locations of load positions of this truck in the calibrated structural model and, Figure 21 shows different influence lines for four (4) beams resulting from 6424 simulations executed by the MATLAB software application, where load magnitude was modified for the six (6) truck axles.

c) Calculation of loads per axle: By means of a convergence process in the genetic algorithm, which is based on a comparison process among different theoretical lines of influence regarding to displacement experimental line of influence (at mid-span of the four implemented beams), loads magnitudes (per axle) were calculated on each truck travelling on the bridge.

For such purpose, the experimental lines of influence of four implemented beams, resulting from C3-S3 truck passing along the bridge (as above mentioned), are presented below. 


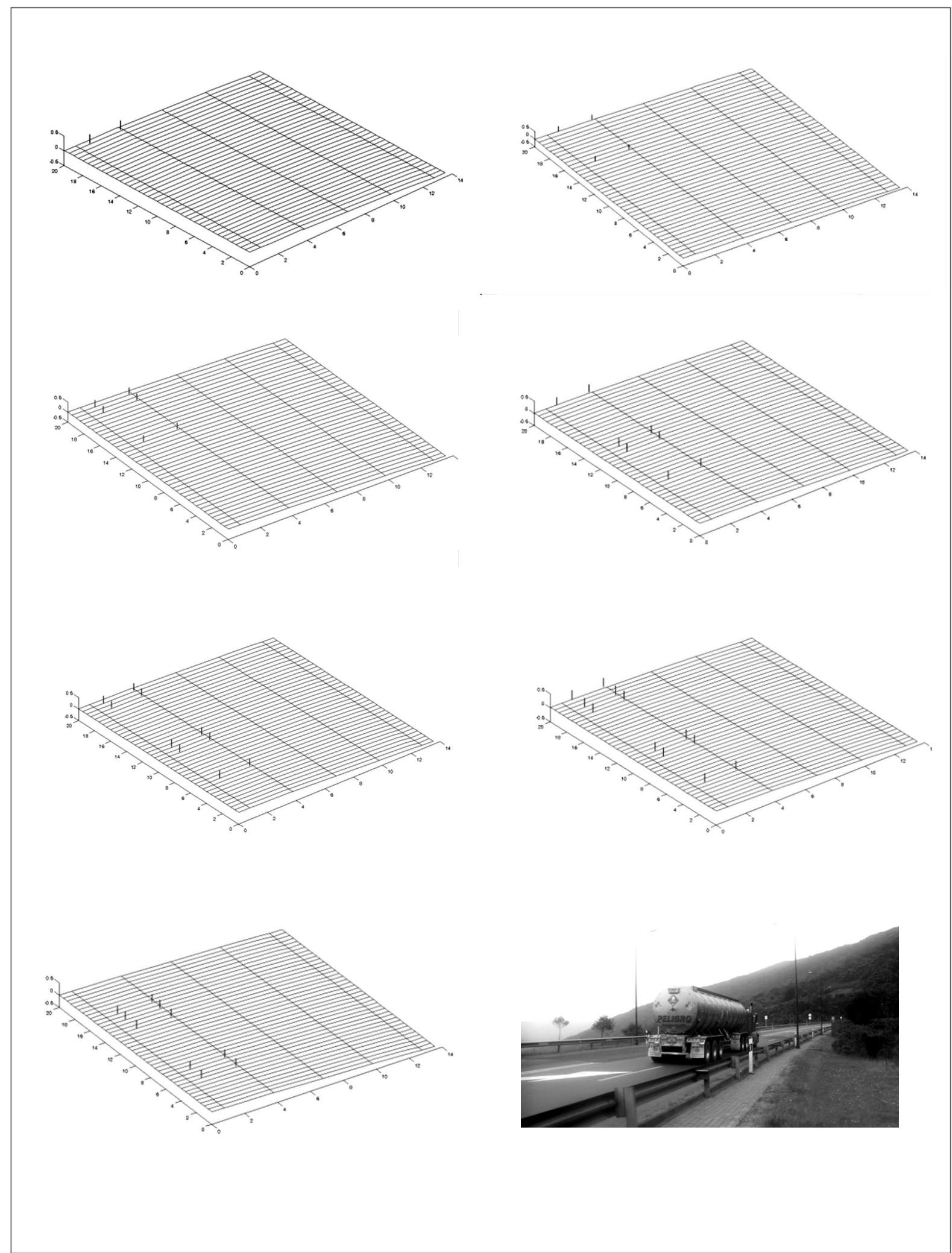

Figura 20. Algunas posiciones de carga generadas por el camión C3-S3 cuando circula por el carril de la vía Villavicencio-Bogotá para su simulación en el modelo estructural calibrado en MATLAB. Registra datos desde que el camión entra hasta que sale del puente

Figure 20. Some load positions generated by C3-S3 trucks when travelling on

Villavicencio-Bogota lane for its simulation in calibrated structural model by MATLAB. It registers data from the moment the truck enters the bridge until leaving the bridge 


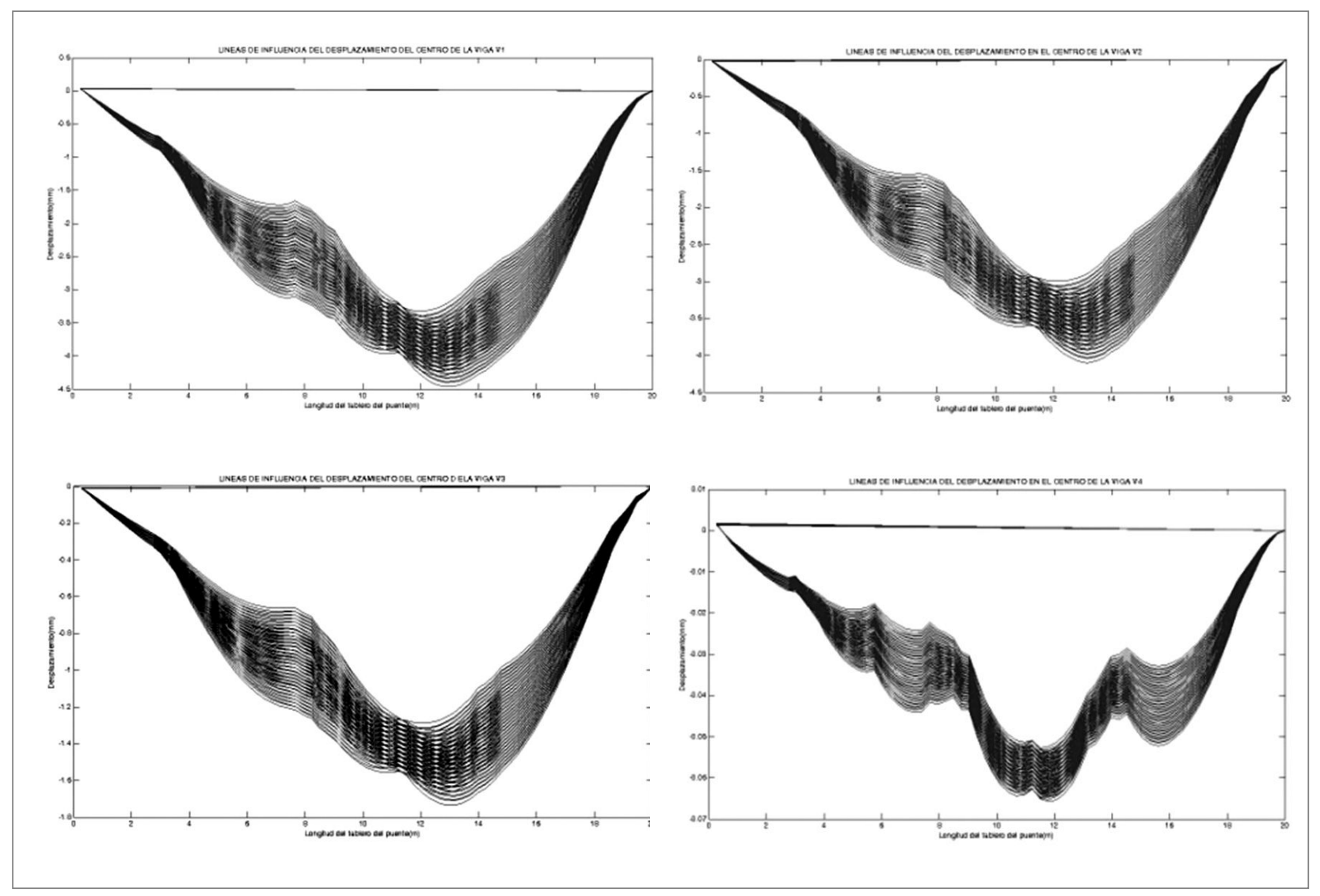

Figura 21. Líneas de influencia TEORICA del desplazamiento en el centro de la luz del puente en las vigas V1, V2, V3 y V4 Figure 21. THEORETICAL Lines of influence for displacement at the mid span of bridge beams V1, V2, V3 and V4

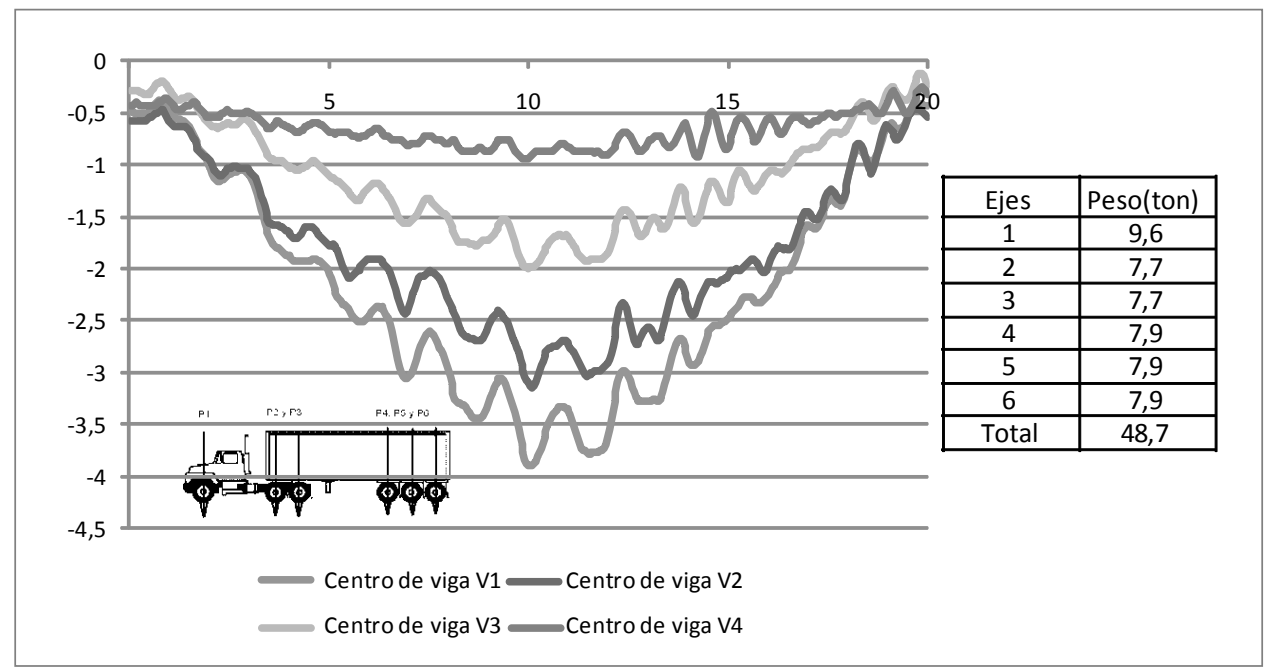

Figura 22. Líneas de influencia EXPERIMENTAL del desplazamiento en el centro de la luz del puente en el centro de las vigas V1, V2, V3 y V4. Peso estático del camión de prueba

Figure 22. EXPERIMENTAL lines of influence for displacement at the mid span of bridge beams V1, V2, V3 and V4. Static weight of tested truck 
From such in-situ information, the first algorithm stage was developed which consisted in calculating the truck total load, considering that weights by axle are equal and, they increase until converging and achieving the average minimum cumulated error, as observed in the following figure:

By employing optimization techniques and considering they work on a solution population, not on a single one only as done by traditional procedures, the second stage of the algorithm was designed, which variables are the weights per each truck axles. In the case of C3-S3 truck, the mathematical process considered six (6) variables and, different calibration tests were carried out, including impact variations between $10 \%$ and $30 \%$, thus concluding that with $22 \%$ the best solution is achieved based on a convergence process, delivering the minimum cumulated error, which process is explained in Figure 24. Figure 24. Process for final calculation of load per axle on C3-S3 truck.

The following figure presents theoretical lines of influence compared to experimental ones, showing the convergence level and, therefore, the reliability of results achieved from genetic algorithms. An impact of $22 \%$ was obtained which is quite close to the one recommended by CCDSP and also the magnitude distribution of axles with errors ranging from $1 \%$ until $7 \%$, as observed in Table 2.

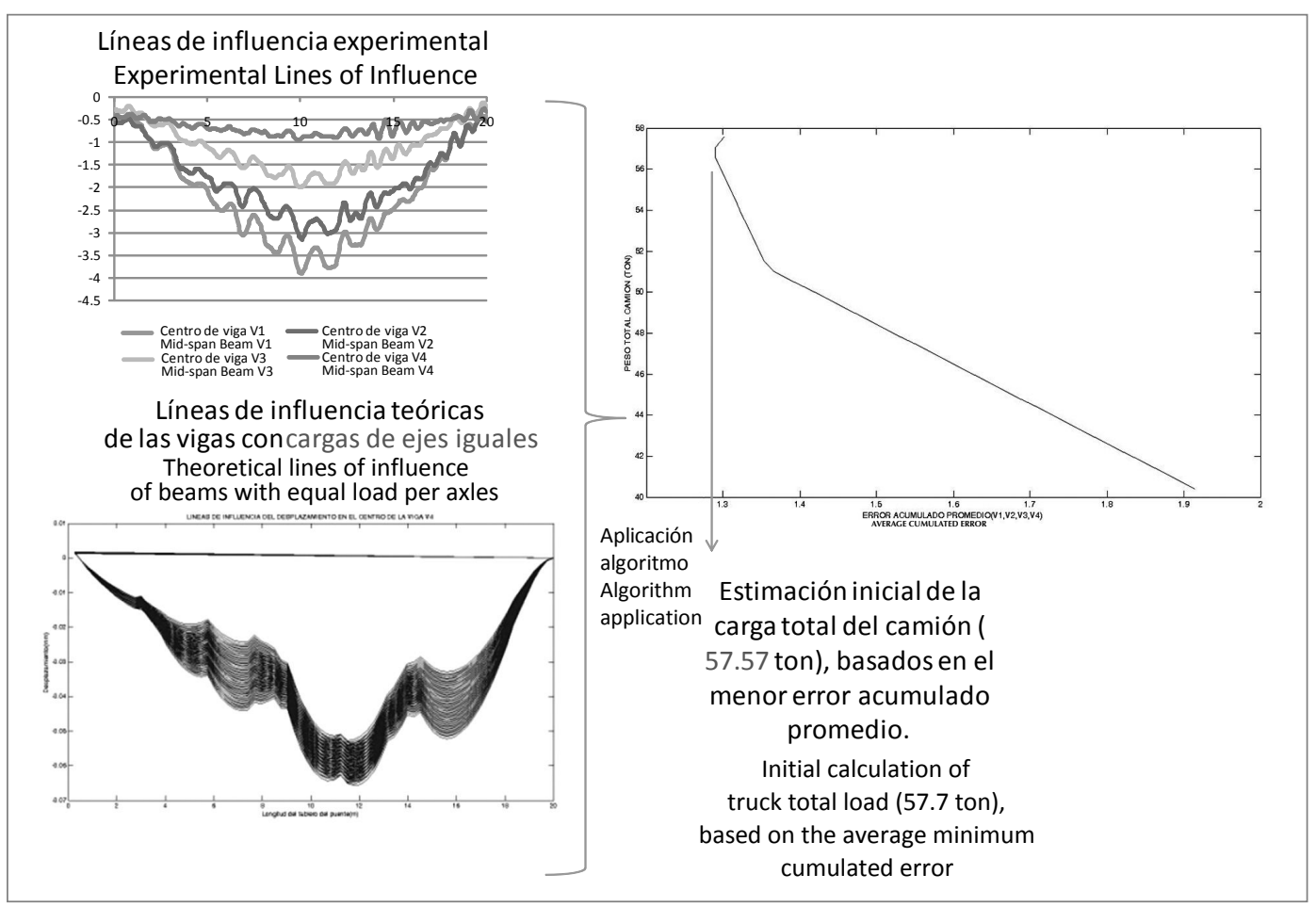

Figura 23. Proceso para la estimación inicial de la carga total del camión

Figure 23. Process for the initial calculation of truck total load 
Puente basado en algoritmos genéticos e instrumentación/Bridge based on genetic algorithms and instrumentation

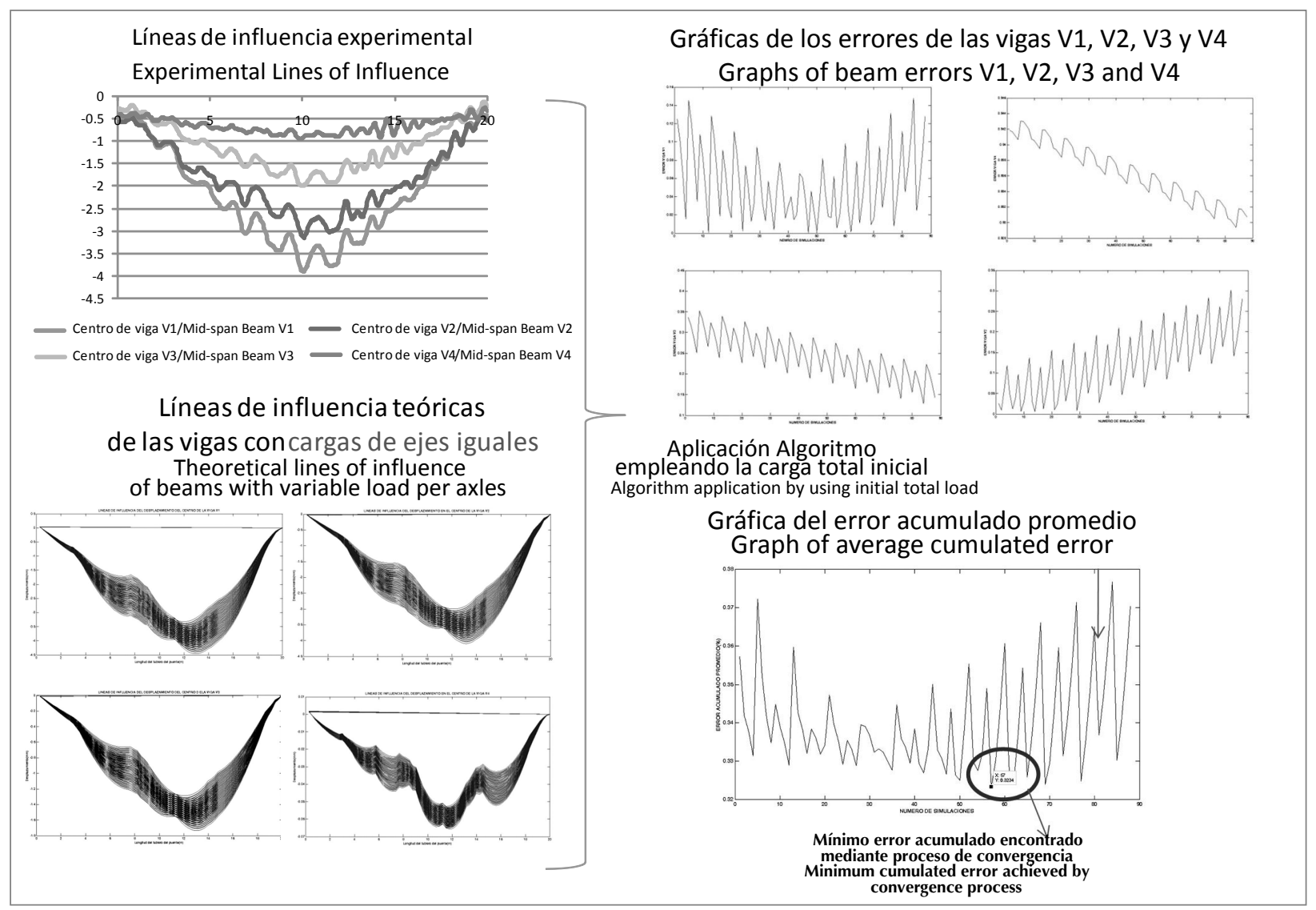

Figura 24. Proceso para la estimación final de la carga por eje del camión C3-S3

Figure 24. Process for the final calculation of truck per axles load C3-S3

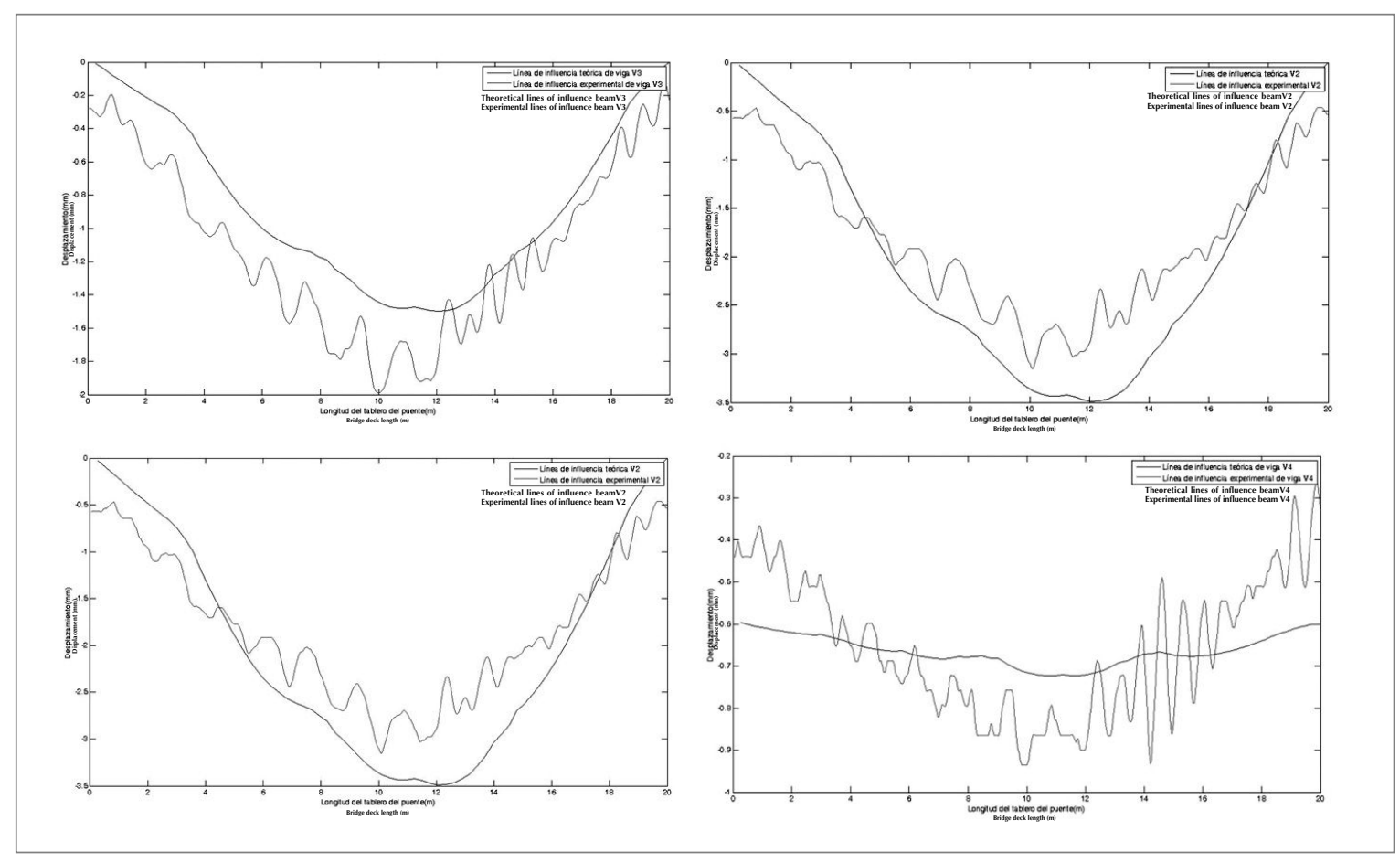

Figura 25. Líneas de influencia teóricas más cercanas a las líneas de influencia experimental Figura 25. Theoretical lines of influence closest to experimental lines of influence 
The same above mentioned procedure was used to include in the algorithm the calculation of total loads and loads per axle for $\mathrm{C} 4$ and $\mathrm{C} 3$ trucks. The concessionaire supplied trucks $\mathrm{C} 4$ and $\mathrm{C} 3$, which geometry and weight were previously known. The following figure shows the results for both (2) trucks, including load magnitudes per determined axles.
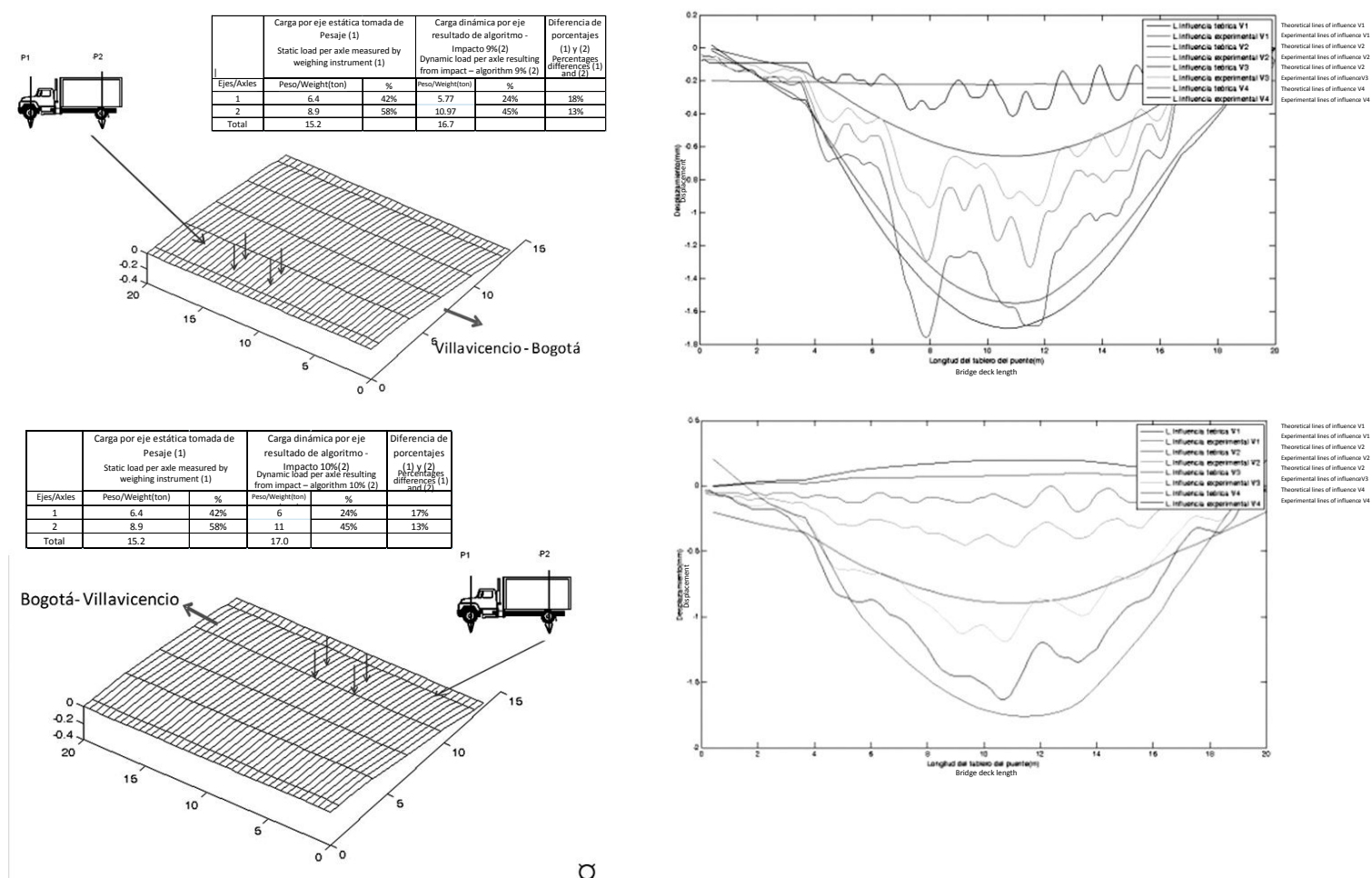

$a$
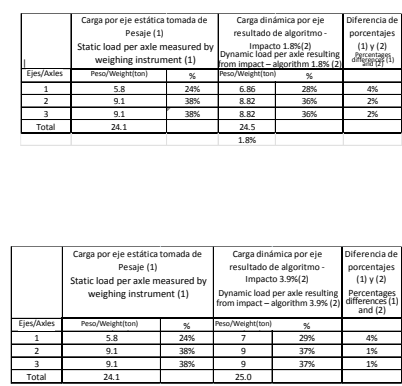

Figura 26. Líneas de influencia teóricas más cercanas a las líneas de influencia experimental de los camiones C3 y C4 en cada dirección Figure 26. Theoretical lines of influence closest to experimental lines of influence on $\mathrm{C} 3$ and $\mathrm{C} 4$, for both carriage ways 


\section{Analysis results}

The genetic algorithm implemented by this pilot test is capable of calculating dynamic loads per axle and total loads for different trucks travelling on the instrumented bridge. However, it calculates trucks loads only when there is one single truck travelling on the lane, i.e., when there is no multiple simultaneous presence of loads on the bridge. It was designed to be adapted for future research jobs, so that it will be able to detect simultaneous and multiple loads moving on one lane or two (2) lanes of the bridge.

Figure 27 presents the results of different C3-S3 trucks travelling on Villavicencio - Bogota lane. Such figure shows that, by means of an algorithm, the relation existing among different variables can be determined, such as: trucks total weight, average deck displacement and trucks speed. From such information it was possible to calculate a potential equation that provides the total weight of C3-S3 trucks (travelling on one lane) in relation to the average deck displacement (See Figure 30 (b)), which is a simplification with adequate reliability resulting from a wide mathematical process that included the structural model calibration, the stiffness matrix and genetic algorithm. Besides, figure 30(c) presents the variations of moving trucks loads per axle in relation to their speed. This relation allows the comparison of moving loads per axle regarding established limits, which is a preliminary weighing control tool quite useful for the concessionaire so as to decide the implementation of this system on a permanent basis. By means of this mechanism it is possible to report or identify the weight of a truck, which shall be checked by a weighing toll gate thus conducting a most adequate control. 

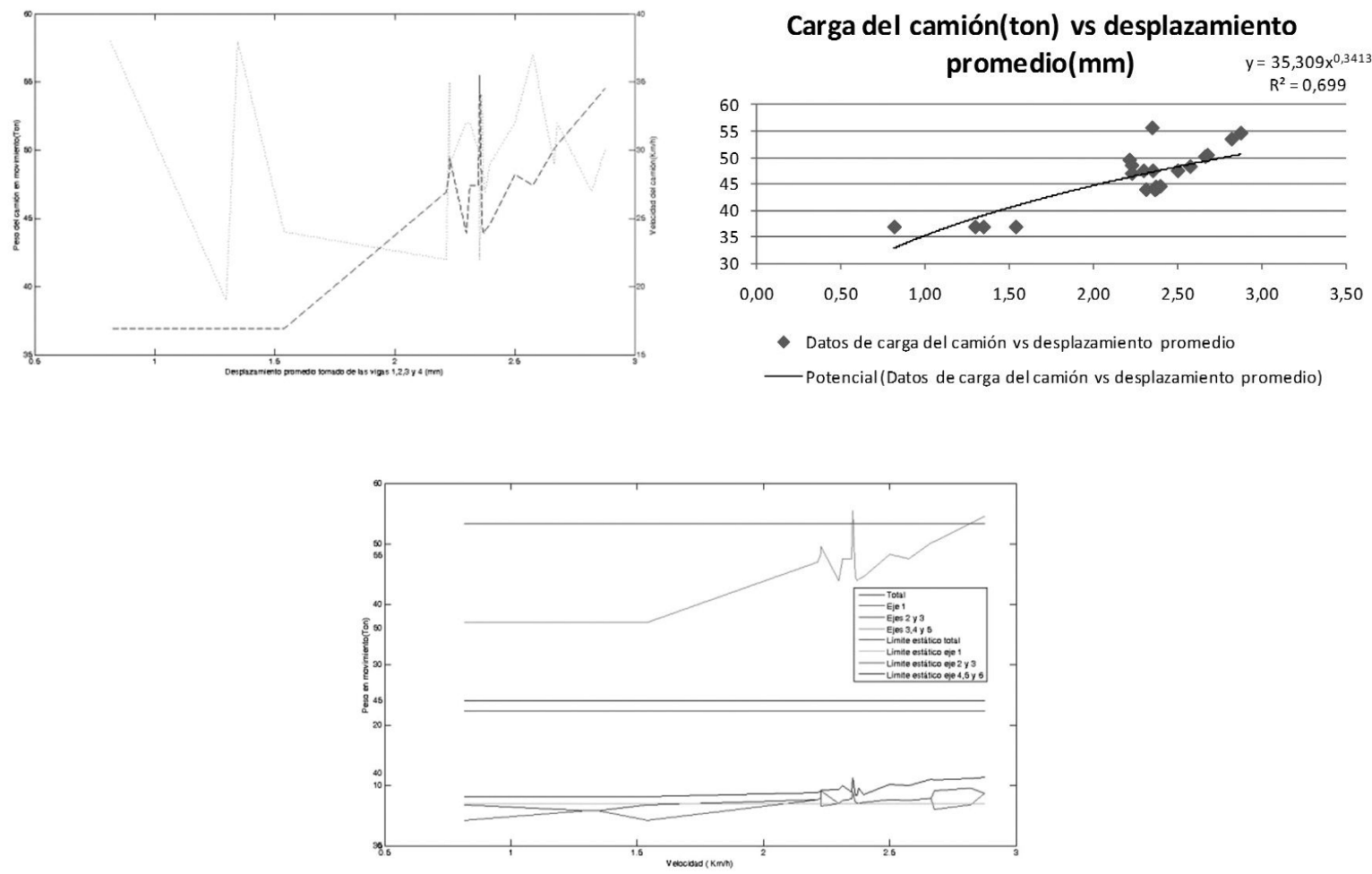

Figura 27. (a) Peso total en movimiento vs Desplazamiento promedio de las vigas del puente (V1, V2,V3 y V4) Velocidad de los camiones vs Desplazamiento promedio de las vigas del puente $(\mathrm{V} 1, \mathrm{~V} 2, \mathrm{~V} 3$ y V4). (b) Determinación de la función de tendencia que relaciona los desplazamientos de las vigas con la carga total del camión. (c) Parte de Líneas de influencia teóricas más cercanas a las líneas de influencia experimental de los camiones $\mathrm{C} 3$ y C4 en cada dirección.

Figura 27. (a) Total moving weight v/s Average displacement of bridge beams (V1, V2, V3 and V4). Trucks speed v/s Average displacement of bridge beams (V1, V2, V3 and V4). (b) Calculation of trend relating beams displacements with truck total load. (c) Some theoretical lines of influence closest to experimental influence lines of trucks C3 and C4 in both carriage directions

The following figures present the total moving weight of trucks C3-S3 during 24 hours (day and night time) including the average deck displacement. By means of the following graphs the following facts can be identified, as observed in Figure 32:

- Highest frequency time for this type of trucks

- Moving loads average

- Time of maximum and minimum loads

- Among others 
Puente basado en algoritmos genéticos e instrumentación/Bridge based on genetic algorithms and instrumentation

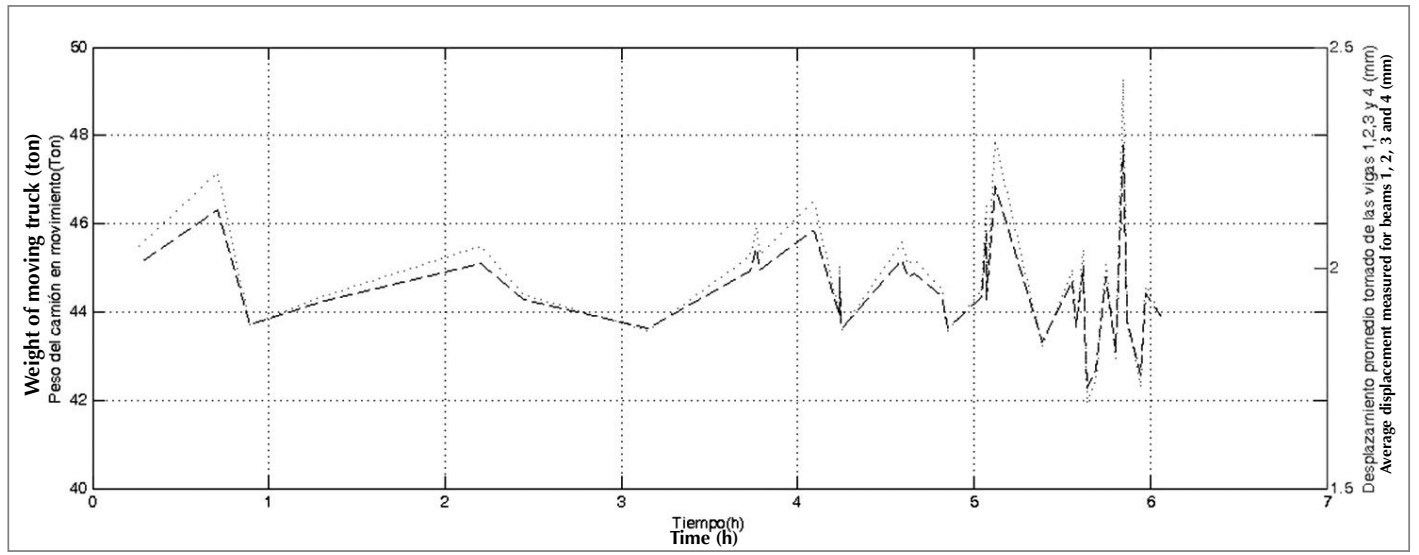

Figura 28. Peso total en movimiento y desplazamiento promedio de las vigas del puente (V1,V2,V3 y V4) desde las 0 a 6 horas. Número de camiones C3-S3 detectados: 40

Figure 28. Total moving weight and average displacement of bridge beams (V1, V2, V3 and V4), from 0 to 6 hours. Number of CS-S3 trucks detected: 40

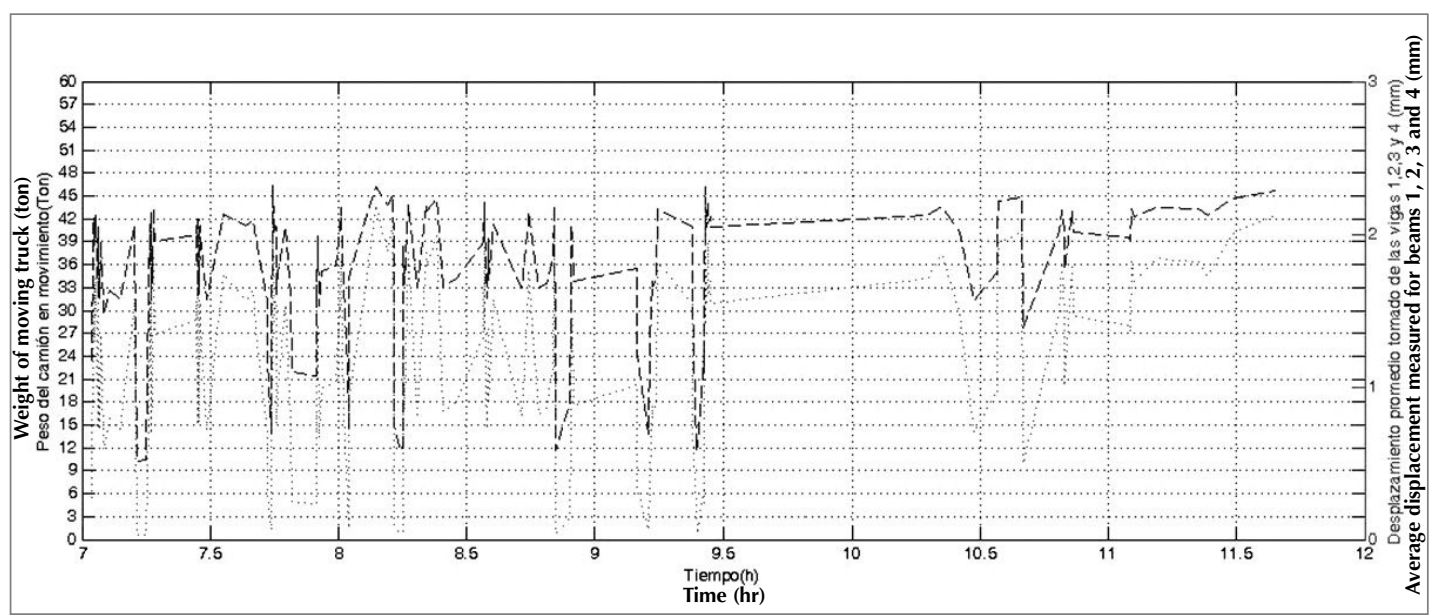

Figura 29. Peso total en movimiento y desplazamiento promedio de las vigas del puente (V1, V2, V3 y V4) desde las 6 a 12 horas. Número de camiones C3-S3 detectados: 176

Figure 29. Total moving weight and average displacement of bridge beams (V1, V2, V3 and V4), from 6 to 12 hours. Number of C3-S3 trucks detected: 176.

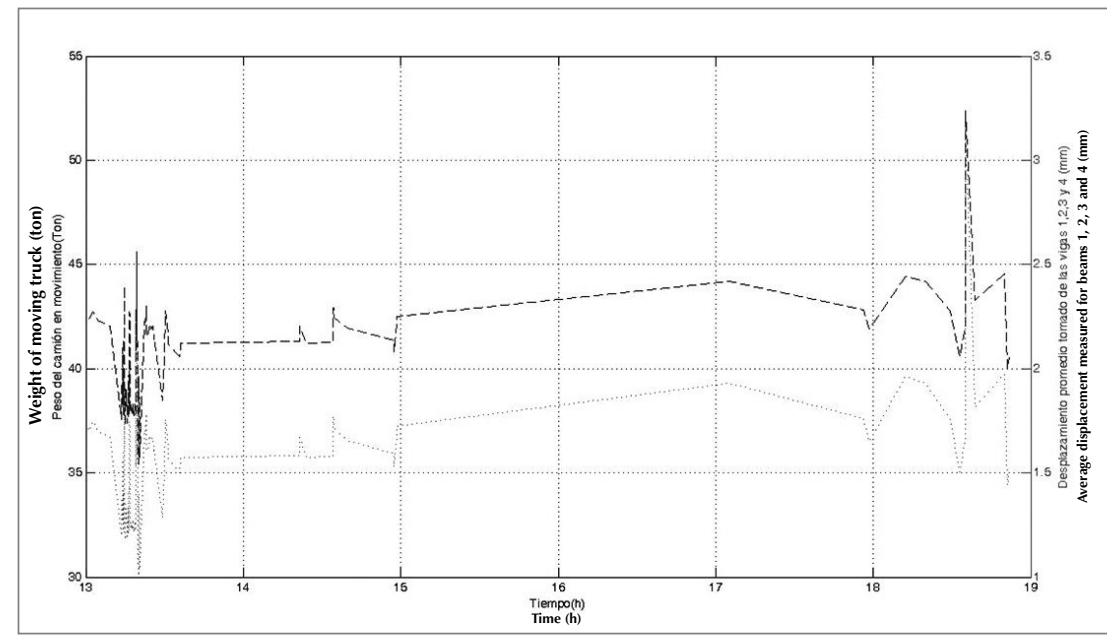

Figura 30. Peso total en movimiento y desplazamiento promedio de las vigas del puente (V1, V2, V3 y V4) desde las 12 hrs. a 18 horas. Número de camiones C3-S3 detectados: 154

Figure 30. Total moving weight and average displacement of bridge beams (V1, V2, V3 and V4), from 12 to 18 hours. Number of C3-S3 trucks detected: 154 


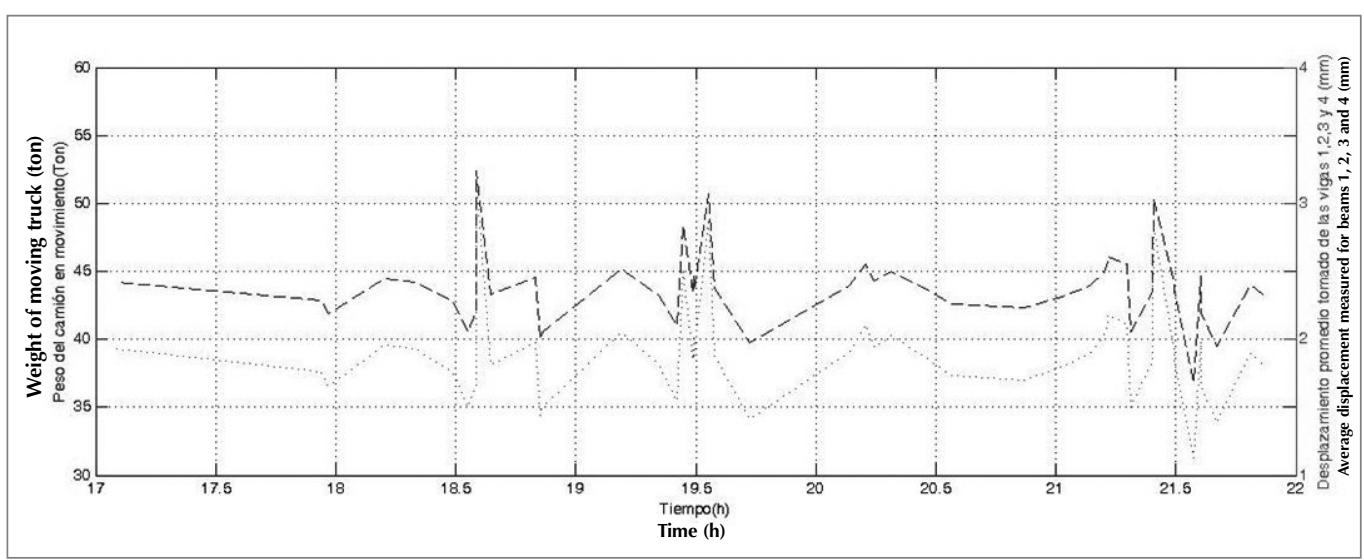

Figura 31. Peso total en movimiento y desplazamiento promedio de las vigas del puente (V1, V2, V3 y V4) desde las 18 a 24 horas. Número de camiones C3-S3 detectados: 152

Figure 31. Total moving weight and average displacement of bridge beams (V1, V2, V3 and V4), from 18 to 24 hours. Number of C3-S3 trucks detected: 152

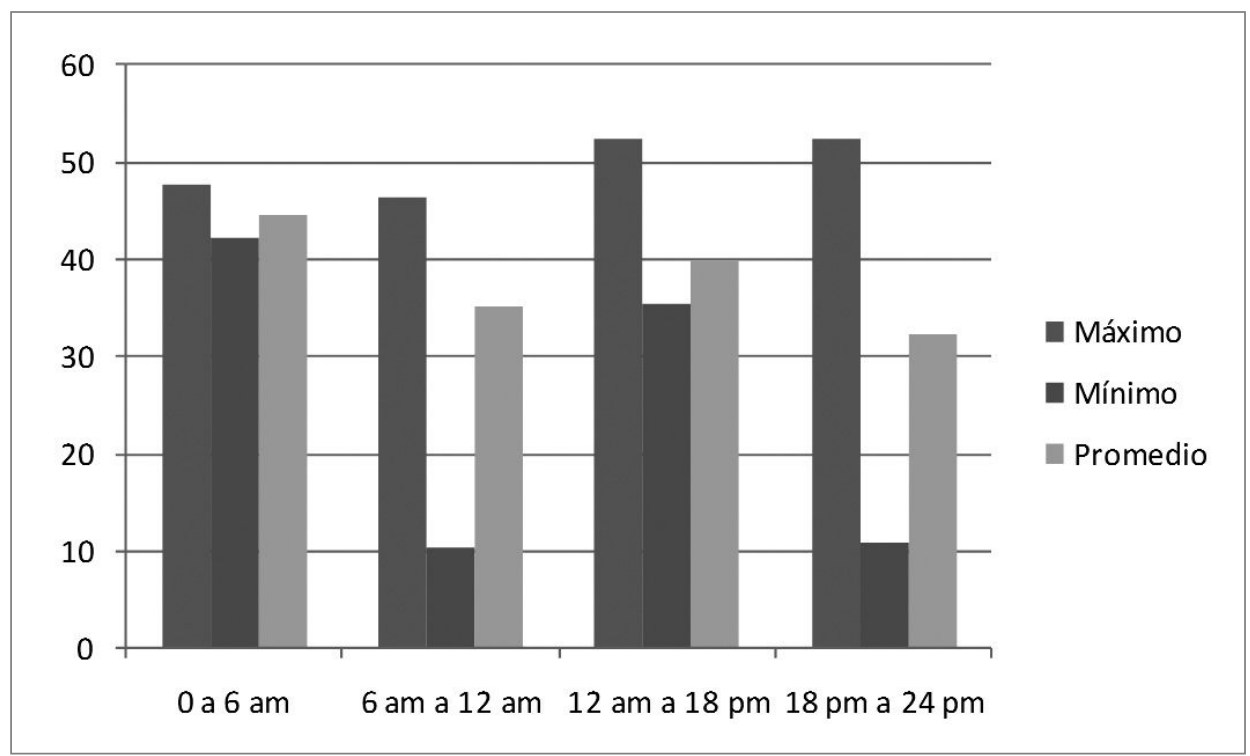

Figura 32. Resumen de la carga y los desplazamientos del tablero en 24 horas de camiones C3-S3 cuando circulan por el carril Villavicencio-Bogotá

Figure 32. Summary of deck loads and displacements during 24 hours for C3-S3 trucks travelling on Villavicencio - Bogota lane

The above example, which values can be extrapolated to each type of truck and lane, demonstrate the advantages of the implemented system, which cost/benefit relation is greater than the one delivered by traditional static weighing system or by WIM, thus becoming a complementary alternative to improve the existing ones. 
Another application of the instrumented system is the automatic measurement of discriminated traffic on the carriage way. Particularly, the pilot test was able to measure trucks discriminating by number of axles. Counting on October 5 th and 6 th do not deliver the values for the whole days; on October 20th because of a canalization lack, the vehicles were likely travelling on a third lane not being sensed by measurement devices; On October 21st and 22nd those inconveniences were solved and the continuous 24 hours measurement system was available on October 21 st afternoon-night time and October 22nd morning, which is the period when trucks' TPD was calculated. By comparing the obtained results to traffic volumes delivered by INVIAS, this device accuracy is proved for measuring traffic volumes, thus becoming a high potential research tool from a traffic and transport engineering point of view.

The obtained trucks' TPD in the current pilot test was 5858; trucks' TPD reported by INVIAS for 2008 was 5153, which with a moderate growing rate could reach from 5500 to 5800 for 2010, thus demonstrating the soundness of automatic traffic measurements by means of sensors installed in the ground. A great similarity is found in the comparative analysis of percentage distribution obtained from pilot test and the one delivered by INVIAS. The pilot test in the current research job delivered a weighing percentage distribution of $76 \%, 5 \%, 11 \%$ and $8 \%$ for C2, C3-4, C5 and >C5; the volumes by INVIAS delivered a weighing percentage distribution of $64 \%, 10 \%, 10 \%$ and $16 \%$, for $\mathrm{C} 2, \mathrm{C} 3-4, \mathrm{C} 5$ and $>\mathrm{C} 5$, respectively.

Another possible application for heavy load weighing system from a transport engineering point of view, is the supply-demand studies on vehicles load calculation; presently such studies are carried out by means of opinion polls applied on a sample of load vehicle drivers, avoiding subjectivity involved in the survey group answers; therefore surveys could be focused on other variables such as origin/destination and the kind of load transported. 
On the other hand, this pilot test enabled data collection on the vehicles speed, which also evidences a strong soundness. For example on October 21 st and 22nd, the average speed on Bogota - Villavicencio direction was 38.3 and 38.5 , respectively, and on Villavicencio- Bogota direction was 32.3 and 32.0, respectively. Such vehicles speed difference of approximately $20 \%$ is originated by the fact that there was a weighing toll few meters behind, contrarily on the other direction there was no traffic restriction.

Counting with reliable speed records has several advantages, understanding that speed is a fundamental variable to establish servicing level on a traffic road. Such speed automatic measurement, in future implementations could facilitate an accurate approximation of service level on a carriage way at a given moment, which is quite useful especially for concessional carriage ways, where servicing level is quite important for users. By means of on-line speed monitoring, the concept of servicing level can be increased, which indirectly has wide consequences for investments and gradual stages of civil works. Therefore, so as to provide an operational servicing level to users, the carriage way operation should not be higher than Service D, more than $\mathbf{5 0}$ hours a year; this information can be easily collected by means of devices such as the ones used in the current pilot test. Other applications may be available, those related to dynamic signaling, information to users, road assistance, operation under special conditions and critical traffic conditions, elements that could be reported by using some routines based on speed.

Finally, information as the one collected by this pilot test has the potential to contribute in control issues for load transportation on Colombian highways. Apart from above explained variables such as weight, traffic volume and speed; quite useful information could be collected for the determination of load transportation fare rates, which is a controversial subject between transporters and regulatory authority in our country, mainly because of dissymmetry of existing information. The global trend is deregulation, thus forcing the Governments role to focus on service quality issues. 
For example, for the determination of standard load transportation basket, it is usual that transporters declare their arguments such as the unloaded trips developed, that diminishes their business profit. If employed measurement devices are complemented with plate collection devices by means of video recordings, it will be possible to obtain weigh information associated to plates and, to learn with higher accuracy if in some origins/destinations there is a load compensation or not. This information would be useful for the regulatory authority on subjects such as freight determination among others, so as to collaborate in increasing the efficiency mode by understanding that transportation costs are a very important factor in logistic costs for products.

\section{Conclusions}

- Methodology based on Genetic Algorithms supported on Influence Lines developed in the current research job, enables an easy determination of highly reliable dynamic loads produced by heavy trucks travelling on an instrumented bridge, as well as obtaining discriminated vehicular traffic volume by vehicle type, with great efficiency when compared to static measurement traditional processes.

- The average calibration error of $4.6 \%$ delivered by the analytical model application on the bridge superstructure, starting from a static test and followed by the optimization numerical techniques on the bridge behavior, are quite acceptable considering the complex actions and effects of these types of structures.

- A qualitative and quantitative contribution from this research job is the determination of stiffness matrix of bridge superstructure, which is based on a calibrated analytical model application which is the base of genetic algorithm.

- The calibration and validation process of genetic algorithm considering the transit of different trucks, counting with previous information on weight and geometry employed in this research job, proved to be more accurate when determining higher load magnitudes per axle, especially for trucks C3-S3 and C3-S2.

- The system developed has the capacity of determining with satisfactory accuracy the total weight in motion for any kind of truck, during day and night times, on each lane based on the average displacement of four beams. 
- The employed system may be implemented on a preliminary basis on supported single span bridges in Colombia, so as to complement traditional static weighing systems thus allowing the optimization of weighing control tasks.

\title{
6. Acknowledgments
}

\author{
Current research job was developed thanks to \\ logistical support provided by COVIANDES.
}

\section{Referencias / References}

Acevedo A.M y Martínez L.A (2006), “Diseño de algoritmos para la determinación indirecta de las cargas dinámicas de los carros que actúan sobre un prototipo instrumentado del puente puerto Salgar", Trabajo de grado, Director: Edgar Muñoz, Pontificia Universidad Javeriana, Departamento de Ingeniería Civil.

European Commission 4th Framework Programme Transport(2001), "Weighing-in-motion of Axles and Vehicles for Europe (WAVE)" Report of Work Package, Bridge WIM systems (B-WIM), University College Dublin.

Goldberg D. (1989), Genetic Algorithms in Search, Optimization and Machine Learning. Addison Wesley. 412 pp.

Gagarine N. (1991) Advances in weigh-in-motion with pattern recognition and prediction of fatigue life of highway bridges, Ph.D. thesis, Department of Civil Engineering, University of Maryland, College Park, Md, USA,.

Muñoz E.E. (2001), "Estudio de las causas del colapso de algunos puentes de Colombia". Revista Ingeniería y Universidad, Pontificia Universidad Javeriana, Bogotá, Colombia.

Muñoz E.E., Nuñez F. F. y Jamshid Mohammadi (2009), "An Investigation of Common Causes of Bridges Collapse in Colombia", ASCE - Practice Periodical on Structural Design and Construction, EE.UU.

Muñoz E.E., Valbuena E. y Rodríguez R. (2004), “Estado y daños típicos de los puentes de la Red Vial Nacional de Colombia, basados en inspecciones visuales". Revista RUTAS, Asociación Técnica de Carreteras, Madrid, España.

Muñoz E.E. y Valbuena E. (2004), "Evaluación de los puentes de acero de la Red Vial Nacional", Revista internacional de desastres naturales, accidentes e infraestructura vial, Universidad de Puerto Rico, Puerto Rico.

Muñoz E.E. y Valbuena E. (2006), “Los problemas de la socavación en los puentes de Colombia”, Revista de Infraestructura Vial, numeral 15 de febrero de 2006, Lananme, Universidad de Costa Rica, San José.

Muñoz E.E., Nuñez F., Otalora XX., Rodríguez W.n y Ruiz D. (2006), “Confiabilidad estructural de un puente en acero apoyados en monitoreo e instrumentación", Revista Ingeniería de Construcción, Pontificia Universidad Católica de Chile, Chile.

Muñoz E.E., Rodríguez J., Nuñez F., Otalora C. y Ramos A. (2008), "Vulnerabilidad sísmica y capacidad de carga de un puente en acero basado en confiabilidad estructural", Revista Ingeniería de Construcción, Pontificia Universidad Católica de Chile, Chile.

Muñoz E.E., Rodríguez J., Nuñez F., Otalora C. y Ramos A. (2010), "Vulnerabilidad sísmica de un puente atirantado basada en confiabilidad estructural y apoyado en monitoreo e instrumentación", Revista Ingeniería de Construcción, Pontificia Universidad Católica de Chile, Chile.

Moses F. (1979), Weigh-in motion Sytem using instrumented bridges. Transportation Engineering Journal , ASCE, 105, TE3, 233-249

Pino L. A. (2006), "Propuesta para la elaboración de norma para la evaluación de superestructura de puentes de carretera existentes en Colombia", Trabajo de grado, Pontificia Universidad Javeriana, Departamento de Ingeniería Civil.

Quilligan M.(2003), “Bridge Weight-in-motion. Development of a 2-D Multi-Vehicle Algorithm", Department of Civil and Architectural Engineering. Royal Institute of Technology, Stockholm, Sweden.

Rowley C., Gonzalez A. Obrien E. y A. Znidaric (2008), "Comparison of conventional and regularized bridge weigh-in-motion algorithms," in Proceedings of the 5th International Conference on Heavy Vehicles (ICWIM '08), pp. 271-282, Paris, France.

Tarantola A. (2005), "Inverse Problem Theory and Model Parameter Estimation". SIAM. New Jersey.

Chan T. H. T. y Ashebo D. B. (2006), "Theoretical study of moving force identification on continuous bridges," Journal of Sound and Vibration, vol. 295, no. 3-5, pp. 870-883.

Chan T. H. T. y Ashebo D. B. (2006), “Moving axle load from multi-span continuous bridge: laboratory study," Journal of Vibration and Acoustics, Transactions of the ASME, vol. 128, no. 4, pp. 521-526.

Law S. S., Chan T. H. T. y Zeng Q. H. (1997), “Moving force identification: a time domain method," Journal of Sound and Vibration, vol. 201, no. 1, pp. 1-22.

Law S. S., Chan T. H. T. y Zeng Q. H. (1999), "Moving force identification a frequency and time domains analysis," Journal of Dynamics Systems, Measurement, and Control, vol. 121, no. 3, pp. 394-401.

Zhu X. Q. y Law S. S. (2000), "Identification of vehicle axle loads from bridge dynamic responses," Journal of Sound and Vibration, vol. 236, no. 4, pp. 705-724.

Znidaric J. y Moses F. (1994), "Evaluation of the Carrying Capacity of Existing Bridges". Final Report. Institute for Testing And Research in Materials and Structures. Ljubljana, Slovenia. 